\title{
Şevket Süreyya Aydemir'in Tarihî Metinlerinde Türk İnkılâbına Eleştiriler
}

\section{Criticisms of the Turkish Revolution in the Historiography of Şevket Süreyya Aydemir}

\author{
Ferit Salim SANLI ${ }^{1}$
}

'Sorumlu yazar/Corresponding author: Ferit Salim Sanlı (Dr.),

Hacettepe Üniversitesi, Atatürk Ilkeleri ve Inkılâp Tarihi Enstitüsü, Ankara, Türkiye

E-posta: fssanli@hacettepe.edu.tr

ORCID: 0000-0001-9010-5620

Başvuru/Submitted: 26.01.2021

Revizyon Talebi/Revision Requested:

09.02.2021

Son Revizyon/Last Revision Received:

25.02.2021

Kabul/Accepted: 10.03.2021

Online Yayın/Published Online: 17.04.202

Atıf/Citation: Sanlı, Ferit Salim. "Şevket Süreyya Aydemir'in Tarihî Metinlerinde Türk Inkılâbına Eleştiriler." Türkiyat Mecmuası-Journal of

Turkology 31, 1 (2021): 341-374.

https://doi.org/10.26650/iuturkiyat.869005

\section{öz}

Şevket Süreyya Aydemir cumhuriyet dönemi Türk fikir hayatının önemli isimlerinden birisidir. Cumhuriyet dönemi fikir hayatına damga vuran "Kadro" hareketinin baş ideoloğu olan Aydemir, 1960' ıııllarda çok etki yaratmış olan "Yön" dergisinin de yazar kadrosunda yer almıştır. Aydemir, 1960'lı ve 1970'li yıllarda sırasıyla Atatürk, İsmet İnönü, Adnan Menderes ve Enver Paşa'ya dair biyografiler kaleme almış ve "mihver şahsiyet" olarak gördüğü bu kişiler üzerinden, Modern Türkiye Tarihi yazmıştır. Aydemir'in biyografileri tetkik edildiğinde, ele aldığı bütün dönemlere dair benzer eleştirilerde bulunduğu müşahede edilmiştir. "Doktrin ve kadro" adamı olarak Aydemir, Türk inkılabının derin bir felsefî sisteme dayanmadığını çünkü inkılabı gerçekleştiren şahsiyetlerin böyle bir formasyondan gelmediğini ileri sürmüştür. Bu noktada "aydın" zümresinin, inkılaba öncülük etme misyonu olması gerektiğini düşünen Aydemir hem bürokratik çarkların söz konusu zümrenin önünü kapadığını hem de aydınların bu idealizme sahip olmadığını düşünmektedir. Aydemir'e göre Türk İnkılâbı bilhassa Atatürk döneminde önemli bir aşama kaydetmiş olsa da Atatürk sonrasında "ikmal edilmeliydi" ancak yerine gelenler bunu gerçekleştiremedi.

Anahtar kelimeler: Şevket Süreyya Aydemir, Biyografi, Türk İnkılâbı, Doktrin, Aydın

\section{ABSTRACT}

Şevket Süreyya Aydemir is one of the important figures of Turkish intellectual life in the Republican period. Aydemir, the chief ideologist of the "Kadro" movement, which marked the intellectual life of the Republican period, was also on the writing staff of "Yön" journal, which had a lot of influence in the 1960s. In the 1960s and 1970s, Aydemir wrote biographies in order of about Atatürk, İsmet Inönü, Adnan Menderes and Enver Paşa, and wrote A History of Modern Turkey through these people, whom he considered as "axis personalities". When Aydemir's biographies were examined, it was observed that he made similar criticisms of all the periods he dealt with. As a man of "doctrine and cadre", Aydemir claimed that the Turkish revolution was not based on a deep philosophical system because the personalities who carried out the revolution did not come from such a formation. At this point, Aydemir, who thinks that the "intellectual" group should have the mission to lead the revolution, believes that both bureaucratic wheels are blocking the way of this group, and also 
those intellectuals do not have such an idealism. According to Aydemir, although the Turkish Revolution achieved an important stage, especially during the reign of Atatürk, it should have been "replenished" after Atatürk, but those who replaced it could not achieve this.

Keywords: Sevket Süreyya Aydemir, Biography, Doctrine, Turkish Revolution, Intellectual

\section{EXTENDED ABSTRACT}

Şevket Süreyya Aydemir, one of the important intellectual men of the Republic period, published biographies entitled "One Man" in three volumes between 1963 and 1965, "the second man" in three volumes between 1966 and 1968, "the drama of Menderes" in 1969 and "Enver Pasha from Macedonia to Central Asia" in three volumes between 1970-1972. In fact, Aydemir conducted a kind of research on the history of Modern Turkey in the light of these biographies. Remzi Press, where biographies have already been published, has also revealed the nature of these works by using the phrase "the last century of our recent history has been completed" on the back of the last volume.

Turkey's 1960s were very interesting in terms of the history of political thought as well as political history. Because at this time when doctrinal political parties were founded, doctrinal political movements also acted with the motto "this order must change", while both right and left movements put forward ideas in which socio-economic analysis was intensive. At this point, Aydemir, who wrote series of biographies during the period in question, seems to have brought quite important criticisms, sometimes explicit and sometimes tacit, about the process of the Turkish Revolution.

Aydemir, does not consider the historical event in which happened in 23 July 1908 called as the "ikinci meşrutiyet" as a revolution, because according to him, in that event whether the Sultanate regime, the internal structure of the state, or any of the religious institutions were changed. At this point, Aydemir, a man of "doctrine and cadre", criticizes that there is no world, no ideas, no composition of systems in the Young Turks movement, in short, there is no basis for a doctrine. He states that the groups fighting for legitimacy do not enter into a theoretical discussion such as "natural rights", "divine rights", which have a place in the history of political thoughts, work only for a parliamentary institution, that is, a status without intellectual depth, so the Young Turks movement can be considered as "not a struggle for ideas and doctrine", but an "adaptation" effort.

In Aydemir's article, there are sometimes tacit, sometimes explicit, but intense criticism of the process of "revolution" of the Ataturk era. According to Aydemir, Atatürk and his friends created a new state after winning a "great victory" in the national struggle, now "economic and social Dumlupinars" were needed, because Turkey had to become an equal country politically and economically in a backward, Asian country, civilized world, and be cleansed of the remnants of medieval class and feudalism. But what had to be done to win "economic 
and social Dumlupinars" in the process of Turkey's revolution was not fulfilled "as much as necessary". For a "backward and underdeveloped" country such as Turkey to develop rapidly and form its national economy, the ways to be chosen, the procedures to be followed were not specific. At the Izmit interview, Atatürk said that he would not turn his back on foreign capital, and the Izmir economic Congress, which convened later, represented complete liberalism. This was a "late born and late" liberalism for Turkey because the world was no longer a nineteenthcentury world, the free market in the world was fragmented, Europe had lost its ability to be the economic center of the world. The new leaders of Turkey still looked at the liberal and individual Western Europe of the nineteenth century. In this vein, Aydemir's most objected point was the 1924 Constitution.

According to Aydemir, the most important mission of the Inönü period was "to replenish Atatürk". Of course, doctrinism could not be expected from Inönü, who was not a doctrinaire, but the territorial revolution could be carried out, class domination, oligarch colonialism, and Ashraf-ayan derivation could be put to an end. By expanding statehood, great facilities could be created, and capitalism and class fights in the classical sense could not be challenged. Secularism could be deepened; a revolutionary education could be applied instead of "copy education from the West". During the reign of Atatürk, the peasant was "untouched", while socioeconomic problems in the East continued. Because of this, a populist, secular, revolutionary, interventionist" national republic "should be established with the order of the" national chief", and the dynamism of the revolution should be ensured. Inönü failed to meet these expectations.

"To continue and replenish Atatürk"; according to Aydemir, this was not possible after Atatürk's death. Now it was the Democratic Party's turn to make it happen. The DP had previously given bad signals on May 29, 1950. Menderes discussed the revolutions that took place during the Republic period by classifying them as "revolutions that cost the people or did not cost the people". In this speech, Menderes also portrayed the May 14 elections as an important revolution that could not be measured by what had been held up to that time. Aydemir, while evaluating the revolutions before him as mild, thought that Menderes signaled a change in the "social structure" and realized it "willingly or unwillingly". In this speech, Menderes "did not commemorate Atatürk", broke all the ties left behind by not mentioning the stages such as the abolition of the reign and the introduction of popular rule as the stages of the transition to a multiparty order. DP and Menderes used religion in politics in every sense, contrary to the revolution, and had a "cheap earning experience" by translating the "azans read in the nation's own language" into Arabic in the early days of its power. Although Turkey was the first example of National Liberation Movements, at the Bandung Conference, the DP government despite the common stance of the Asian and African nations against imperialism, was "the lawyer of the West" not of Atatürk. Since the DP government considered the struggle for independence of Tunisia, Algeria, Morocco as "an internal matter of France", it was hurting the soul of Atatürk. 
On May 27, 1960, a coup took place and the army seized power. But the revolutionaries, who continued the tradition of Ataturk, did not turn the 27 May movement into "economic, social, political" structural changes, they already had no such "horizons". Thus, Atatürk could not be replenished again. When the Revolution triumphed, the fragmentation of the Revolutionary staff was an immutable law of the revolutions. From the French Revolution of 1789 to the Bolshevik Revolution and even the National Liberation Movement of Turkey, this law was valid in all revolutions. By "bowing his head" to this law on May 27, he was soon torn apart and lost his power of enterprise. 


\section{Giriş}

Cumhuriyetin döneminin önemli fikir adamlarında birisi olan Şevket Süreyya Aydemir 1963-1965 arasında üç ciltten müteşekkil “Tek Adam”, 1966-1968 arasında üç ciltten müteşekkil “İkinci Adam”, 1969 yılında "Menderes’in Dramı” ve 1970-1972 arasında yine üç ciltten müteşekkil "Makedonya'dan Orta Asya'ya Enver Paşa” başlıklı biyografiler yayımlamıştır. Aslında Aydemir, bu biyografiler ışığında bir nevi Modern Türkiye tarihi araştırması yapmıştır. Zaten biyografilerin yayımlandığı yayınevi de son cildin arkasında "yakın tarihimizin son yüzyılı araştırmaları tamamlandı" ibaresini kullanarak bu eserlerin mahiyetini ortaya koymuştur. Yaklaşık 6000 sayfaya tekabül eden bu eserler dizisi, mercek altına aldığı liderlerin hayat hikâyelerinin oldukça ötesinde olguları ve yorumları içermektedir. Aydemir'in metinlerinde "tarihî şahsiyet”, "lider”, "kahraman” gibi nitelemeler oldukça yaygındır çünkü Aydemir'e göre tarihî şahsiyet her milletin tarihinden bir şeyler alan ama bir yerde de milletine bir şey katan adamdır. O kendi devrinden bir şey almaz, kendi devrine yön verir. Lider tayin edicidir, devrinin akışına müdahale eder. Öyle ki ondan sonra tarih, o şahsiyeti yetiştiren toplumun ve çağın akışını izlerken, bu akışın üstünde, o tarihî şahsiyetin ruhunun, fikrinin, alın terinin veya kanının izlerini bulur. ${ }^{2}$ Aydemir'e göre "her milletin tarihi, biraz da, bir şahsiyetler geçit resmidir. Tarihî şahsiyet demek; milletin tarihî kaderine şu veya bu şekilde müdahalesi olan etkisi olan ve bu şahsiyetler geçit resmine katılabilen adam demektir. Tarihî şahsiyet; bu geçit resmine katılabilmek için kimseden izin almaz."3 Mihver şahsiyetler "yön ve kader tayin edici" özellikler taşır ve toplum şartlarının mahsulü olup yön tayin edici olamayan kişiler ancak söz konusu liderin çevresi ile kütlesini teşkil eder. ${ }^{4}$

Yukarıdaki alıntılar Aydemir' in, Türk düşünce hayatında oldukça önemli yeri olan Thomas Carlye'nın "Kahramanlar” eserinde çerçevesini çizdiği tarihyazımından etkilenmiş olabileceğini düşündürtür. Zira Carlyle tarihin ancak "büyük adamların biyografilerinden”, "kahramanların hikâyesi” üzerinden okunabileceğini savunmaktadır. ${ }^{5}$ Ancak Aydemir'in tarihî şahsiyetleri, olayların ve kararların manivelalarına her zaman hâkim değildir. Bazen tarihî şahsiyet içgüdülerinin esiri olabilirken", üstünlükleri olduğu kadar zaafları da olan hatta "bir avcının tuzağına, kendi ayakları ile kapılan zavallı serçe kuşları"7 olabilir. Ayrıca tarihî kahramanların da ancak sınırlı görüş ufukları vardır. Onların da alınyazıları sınırlıdır. Ama ne var ki onların bu sınırlı ufuklarla, bu sınırlı anlayışa göre çizilen alınyazıları başlarına geçtikleri devletin önder oldukları toplumun da kaderini etkiler. ${ }^{8}$

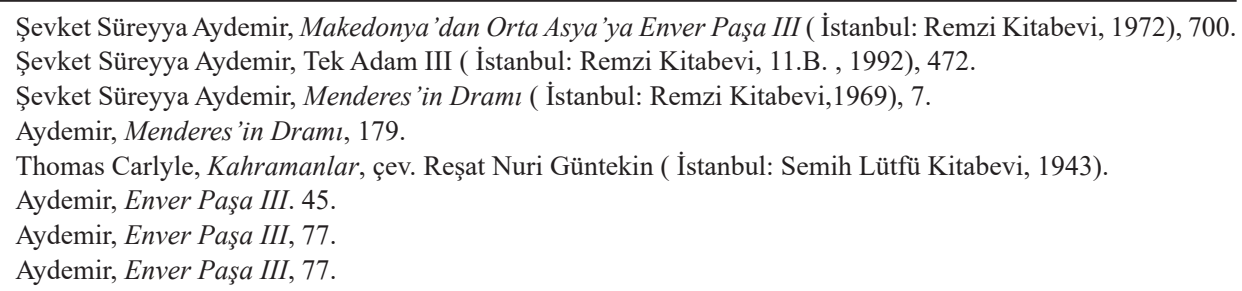


Tarihî şahsiyet ya da kahraman olmayan, kendini "suyu arayan adam” olarak niteleyen Aydemir yaşadığı dönemin ve toplumun ilgi çekici bir figürüdür. Gençlik yıllarında önce Turancı ${ }^{9}$ daha sonra ise Sovyet Rusya deneyimi ile birlikte sosyalist ${ }^{10}$ olan Aydemir, Türk İnkılâbına "sömürge ya da yarı sömürgelere emsal olma" misyonu biçerek bu misyonun kendisini "dünya ihtilâlinin bir peyki sayan" TKP vasıtasıyla değil "inkılâpçı, disiplinli, teşkilatçı, milliyetçi” bir cumhuriyet partisinde gerçekleşebileceği düşüncesiyle CHP'li olmuştur. ${ }^{11}$ Aydemir'in bu dönüşümünün ${ }^{12}$ fikrî altyapısında Sultan Galiyev etkisi olduğu düşünülmektedir. Galiyev’e göre emperyalizm koşulları altında sömürge ve yarı-sömürgelerde sınıflaşma çıkmamıştı ve sömürgecilerin metropollerindeki işçilerin de kapitalizmden istifade etmesi sebebiyle esas mesele sömürgeci ülkelerle yarı-sömürge/sömürge toplumlar arasındaki tezadı gidermekti. Bu noktada Şevket Süreyya, Galiyevist sosyalizmi Türk İnkılâbına uyarlayarak yeni bir ideoloji yaratma yoluna gitti. ${ }^{13}$ Böylece ilk "Millî Kurtuluş Hareketi”'14 olarak gördüğü Türk İnkılâbına nazarî bir prensip vermek ve bu prensipler neticesinde doktrin inşa etmek amacıyla “avangart” bir zümrenin öncülük etmesini savunan "Kadro" hareketinin ideolojik öncüsü oldu. ${ }^{15}$ Kadroculara göre, Kurtuluş Savaşı’nı yürüten kadro herhangi bir sınıfın temsilcisi değildi ve Türkiye henüz kapitalist sistemin kurulmadığı buna mukabil feodal ilişkilerin de belirleyici olmadığı bir dönemdeydi. Bu durum devletin dönüştürülmesi için bir firsattı ve devlet belirli

9 Şevket Süreyya, Müfide Feride'nin meşhur Turancı romanı Aydemir'den mülhem olarak bu soyadını almıştır. Bu romanı, Kafkas Cephesine asker olarak gittiği 1918 yılında okuyan Aydemir, "Hakkın bir ilhamı gibi gelmişti" dediği eseri okuduktan sonra, müstakbel "Turan'ın aydemiri” yani idealist genci olmaya karar verdiğini ifade etmiştir. Bk. Şevket Süreyya Aydemir, Suyu Arayan Adam, (İstanbul: Remzi Kitabevi, 42.B., 2020),120. Aydemir Türkiye'de Turancılık fikriyatının serencamı hakkında da şu değerlendirmelerde bulunmuştur: "Milletlerin hayatlarında her ülkü, az çok hayal ile süslenir. Her idealist de az çok bir hayal adamıdır. Gerçi bu idealist bir kurtarıcı, yeni bir devlet kurucusu yani gerçek bir liderse, asıl yığınları saran hayal ve heyecan dalgaları arkasında o kendi hesaplarını, şartları gerçeklerine uyduracak ve ona göre eylemler düzenleyecek, yön tayin edecektir. Turan ülküsü, bu bahislerde işlenen gençlik yıllarımızın gerçi itici gücüydü. Ama bu ülkü, ne bir eylemci ne de yön tayin edici önderini bulamadığı için Turan davası, daha ziyade bir özlem, hayal ve heyecan kaynağı olarak kaldı. Ve sanıyorum ki en kapsayıcı ifadesini, Kızılelma sembolünde, yani bir belirsizlikte buldu”. Bk. Aydemir, Suyu Arayan Adam, 120.

10 Ahmet Kuyaş, Aydemir'in de dâhil olan müstakbel Kadro hareketi öncülerinin bir dönem sosyalizme temayül göstermesinde, Batı Avrupa'nın hegemonyası altında olan ama bir yerde de yetişme sürecinde Batı Avrupa menşeli fikirlerden etkilenen modernistlerin, söz konusu "aşk-nefret”" ilişkisine dair bir çözümleme çabası olduğu fikrindedir. Kuyaş’a göre sosyalizm, bu isimlere hem batı tarzı bir modernleşme hem de anti-emperyalist bir tavır geliştirme imkânını sunmuştur. Bk. Ahmet Kuyaş, “ Yeni Osmanlılardan 1930'lara Anti-Emperyalist Düşünce”, Modern Türkiye’de Siyasî Düşünce 2:Kemalizm ( İstanbul: İletişim Yay.6.B. 2009), 250.

11 Aydemir, Suyu Arayan Adam, 340.

12 Aydemir'in fikrî değişimlerini Yalçın Küçük “dönek” nitelemesi ile eleştirmekte ve Aydemir'in dönemin Sovyet Rusya literatüründe "renegat” yani dönek olarak tanımlandığını belirtmektedir. Bk. Yalçın Küçük, Aydın Üzerine Tezler 3 (İstanbul: Tekin Yay. 3.B. 1999), 28.

13 Tanıl Bora, Cereyanlar: Türkiye 'de Siyasî İdeolojiler (İstanbul: İletişim Yay. 2.B. 2017), 160-161.

14 Ahmet Kuyaş, Kadrocuların kullandığı "Millî Kurtuluş Hareketi” terminolojisinin fikir babasının Komintern'in Hintli delegesi M.N.Roy olduğunu ve bu fikri henüz 1920’lerde yaptığını ileri sürmektedir. Bk. Kuyaş, "Yeni Osmanlilardan 1930'lara", 252.

15 Kadro hareketi hakkında detaylı bilgi için bk. Temuçin Faik Ertan, Kadrocular ve Kadro Hareketi (Ankara: Kültür Bakanlığı Yay.,1994); Mustafa Türkeş, "Kadro Dergisi”, Modern Türkiye'de Siyasî Düşünce 2: Kemalizm, 464-476. 
bir sınıfı temsil eden bir organ değil, bütün milleti temsil eden bir yapıya dönüştürülebilirdi. Ekonomik ve siyasi gücün devlet elinde toplandığı, özel sektörün de devlet denetiminde tutulduğu bu düzeni devlet, aydın bir kadro ile olan iş birliğiyle sağlayabilirdi. ${ }^{16}$

Kadro dergisi ancak 1935 yılına kadar çıkabildi. ${ }^{17}$ Ancak Aydemir' in yazın faaliyeti muhtelif mecralarda devam etti. 1960'lı yıllar ise Türk inkılâbına istikamet tayin etme hedefini Kadro Hareketi ile gösteren Aydemir'e yeni bir mecra sundu. "Yön"18 adı verilen ve "sosyalist-Jön Türk" olarak nitelenen bu hareket, 60’11 yılların fikrî hayatına damgasını vururken Türk inkılâbına bir "ilerleme ve kalkınma" perspektifi sunmuş ve bu ilerleme-kalkınmanın işçi sınıfı eliyle değil asker-sivil aydın grubu olan "zinde kuvvetler” vasıtasıyla gerçekleşebileceğini savundu. ${ }^{19}$ Literatürde Kadro Hareketi ile mukayese edilen Yön Hareketi her ne kadar Kadro gibi sınıfların oluşumunu "kaygı" ile izleyen bir oluşum olmasa da, Kadro gibi mevcut iktidara hizmet etmeyi değil, mevcut düzeni değiştirmeyi hedeflese de ${ }^{20}$ sosyalizm ile Kemalizmi kaynaştıran ve tepeden inmeci bir ideolojik perspektif çizdi. Bu minvalde Şevket Süreyya Aydemir, iki hareketin ortak noktasını teşkil etti.

Türkiye'nin 1960'lı yılları, siyasî tarih kadar siyasî düşünceler tarihi açısından da oldukça ilgi çekiciydi çünkü doktriner siyasî partilerin kurulduğu bu dönemde, doktriner siyasî akımlar da "bu düzen değişmeli" mottosu ile hareket ederken hem sağ hem de sol hareketler sosyoekonomik tahlillerin yoğunlukta olduğu fikirler öne sürdüler. ${ }^{21}$ Bu noktada söz konusu dönemde biyografi dizileri kaleme alan Aydemir'in eserleri mercek altına alındığında Türk İnkılâbı sürecine dair bazen açık bazen de zımnî olmak üzere oldukça önemli eleştiriler getirdiği müşahede edilir. Literatürde Türk İnkılabına ve bilhassa Kemalizme yönelik liberal, İslamcı, Türkçü perspektiflerden mebzul miktarda eleştiri olmasına rağmen Jakoben nitelikli bir tenkit analizi fazla yer almamaktadır. İşbu makale hem Jakoben hem de Sovyet terbiye sürecinden geçen ve fikirlerine yansıtan Aydemir'in eserlerini mezkûr bağlamda çapraz okuma yapmak suretiyle tahlil ederek Türk İnkılâbına yönelik eleştirilerini tasnif etmeyi amaçlamaktadır.

\section{1-Aydemir'in Tarihî Metinlerinde Cumhuriyet Öncesi Modernleşme Sürecine Dair Eleştiriler}

Aydemir anılarında 1930’lu yıllarda, Halkevleri’nin Ankara sorumlusu olarak bir “'İnkılâp Enstitüsü” kurulması için gayret gösterdiğini ancak inkılâbın ne zaman başladığı hususunda mutabakatın sağlanamadığını belirtir. Aydemir kendisiyle hemfikir olmayan diğer isimleri;

16 Mustafa Türkeş, Kadro Dergisi, 475.

17 Kadro dergisinin imtiyaz sahibi Yakup Kadri Karaosmanoğlu’ndan derginin kapatılış hikâyesini öğrenmek için bk. Yakup Kadri Karaosmanoğlu, Zoraki Diplomat ( İstanbul: İletișim Yayınları, 12.B,2020).

18 Yön hareketi hakkında detaylı bilgi için bk. Hikmet Özdemir, Kalkınmada Bir Strateji Arayışı: Yön (Ankara: Bilgi Yayınevi, 1986).

19 Anıl Varel, “Altmışlı Yıllar Türkiye’sinde Sınıf ve Siyaset: Meşruiyet Savaşımı, Siyasal Yükselişi ve İç Bölünmeleriyle TİP”, Türkiye ’nin 1960’lı Yıllarl, haz. Mete Kaan Kaynar( İstanbul: İletişim Yay.2017), 414.

20 Bora, Cereyanlar, 613.

21 H.Bayram Kaçmazoğlu, “ Bazı Bilim İnsanlarının Türkiye’deki Siyasal Düşün Tarihi Katkıları Üzerine Bir Deneme”, Modern Türkiye’de Siyasî Düşünce 9: Dönemler ve Zihniyetler ( İstanbul: İletişim Yay. 2009), 237. 
“Bütün bir Osmanlı devri yok sayılıyordu... Hâlbuki II. Meşrutiyet, Birinci Meşrutiyet, Genç Osmanlılar, Tanzimat hatta III. Selim'e ve daha gerilere varan bir yenileşme ve garplılaşma mücadelemiz vardı" ${ }^{22}$ demek suretiyle eleştirmiştir. Burada Kemalist tarihyazımına karşın Aydemir' in inkılâba milat olarak cumhuriyet devrini almadığı açıkça görülmektedir.

Aydemir'e göre 19. yüzyılın başından itibaren iktisadî çöküntü içinde olan Osmanlı, bu yüzyılın iktisadî hareketinin çerçevesini çizen Sanayii İnkılâbının dışına kalmış, böylece "makineye sahip olan memleketler" ve "makineden mahrum olan memleketler" olarak ikiye bölünen dünyada, ikinci kısımda yer almıştı. Aydemir, sömürgeyi "yabancı bir devletin hem siyasî-askerî hem iktisadî hâkimiyeti ve nüfuzu altında" olan ülkeler, yarı-sömürgeyi ise "şeklen bağımsız görünmekle beraber, hakikatte gene yabancı ülkelerin imtiyaz ve kontrolleri ve bilhassa iktisadî hâkimiyetleri olan" memleketler olarak tasnif eder. Bundan ötürü 19. yüzy1l Osmanlı Devleti bir "yarı-sömürge" devletidir. ${ }^{23}$

Aydemir, Osmanlı Devleti'nin çöküşü noktasında, “imparatorlukların sonu gelmişti” tezinin aksini ileri sürer ve yeni sömürge imparatorlukları kurmak isteyen "Düvel-i Muazzama”yı örnek gösterir. Buna mukabil Osmanlı'nın çöküşüne sosyo-ekonomik ve idarî bir izah getirir. Mesela Rusya'da monarşik ve emperyal bir yapı vardı ama bu yapıyı destekleyecek teknik ve iktisadî altyapı da mevcuttu. Oysa Osmanlı'da devlet geniş bir coğrafyaya yayılıyordu ama bölgeleri arasında iktisat birliği, pazar birliği, pazarı besleyecek altyapı, yollar ${ }^{24}$, sanayii tesisleri, ziraî mahsul mübadeleleri, yeterli kredi teçhizatı yoktu. Devletin bütçesi haciz, maliyesi ise kontrol altındaydı. Kapitülasyonlarla eli bağlanmış bir yarı-sömürge idi ve bu şartlarda yaşama imkânı yoktu, çağın ileri teknik gelişmesi, çağın hızlı gelişen kültürü karşısında bu "ilkel hayatın" devamı kabil değildi. ${ }^{25}$ Mesela Balkanlar'daki isyanların sebebi, devletin bir idare gücü, iktisat ve kültür birliği yaratamaması sebebiyle gerçekleşiyordu ${ }^{26}$ ve devlet sadece askerî tedbir almak suretiyle sorunu çözmeye çalışıyor bundan ötürü de isyanları doğuran şartlar ve nedenler baki kalıyordu. ${ }^{27}$

Aydemir'e göre, devlet dâhilindeki unsurların tek bir üst kimlik altında yaşatılması fikri olan "Osmanlıcılık" düşüncesi de beyhude bir çabaydı. İmparatorluğu teşkil eden, Türk olmayan halkların önderlerinin ve aydınlarının ruhlarına milliyetçilik işlemişti ve bu aydınlar, önderler

22 Aydemir, Suyu Arayan Adam, 366.

23 Aydemir, Tek Adam III, 340-341. Ahmet Kuyaş’a göre Şevket Süreyya öncülüğünde Kadro hareketinin kısa süre çıkmış olmasına rağmen daha sonraki dönemlere, "Sol Kemalizm", "Millî Demokratik Devrim" gibi düşüncelere esin kaynağı olabilmesinde en önemli amil, "Osmanlı Devleti’nin yarı-sömürgeliği”" kavramı üzerine odaklanmış olmasıdır. Bk. Kuyaş, Yeni Osmanlılardan 1930’lu Yıllara, 252.

24 Aydemir, "yol meselesini” şu sözlere tasvir etmiştir: "Anadolu'nun en büyük hasreti yola idi. Ülkeye girecek her şey yani toprak ürünlerinin kıymetlenmesi, ticaret, sanat, mektep, fabrika yeni bir idare ve yerleşme, eşkıyalığın kalkması ve nihayet ülkenin savunulması yol olursa başarılabilirdi... Bize o zaman öyle geliyordu ki insanoğlunun en mucize eseri yoldur". Bk. Aydemir, Enver Paşa III, 272.

25 Şevket Süreyya Aydemir, Makedonya 'dan Orta Asya 'ya Enver Paşa II (İstanbul: Remzi Kitabevi, 1971), $192-$ 193.

26 Aydemir, Enver Paşa II, 287

27 Aydemir'e göre bu isyanların sadece askerî tedbirlerle bertaraf edilemeyeceğini tek fark eden kişi "imparatorluğun son büyük devlet adamı" Mithat Paşa'dır. Aydemir, Enver Paşa II, 82. 
kendi cemaatlerini yönlendirebiliyordu. "Türkiye'de milliyet duygusundan yoksun olanlar, yalnız Türklerdi. Kendilerini Osmanlı sayıp, Osmanlı birliği ve vatanı için kan dökenler de yalnız onlardı". ${ }^{28}$ Mesela Aydemir'in tarihî şahsiyetlerinden, çocukluğundan beri kendisini vatanı kurtaracak adam olarak gören diye nitelediği Enver ${ }^{29}$, kurmay okulundayken “Allah'ım şu millet-i Osmaniyyeyi kurtar" diye dua ediyordu oysa savaştıkları hep millet-i Osmaniye mensubuydu. Makedonya' da Balkan çetecilerle savaşan Türk subayları arasında "silah farkı" vardı ve bu silah farkı "millî ülkü" meselesi idi. ${ }^{30}$

Aydemir tarihte II. Meşrutiyet olarak geçen 23 Temmuz 1908 hadisesini inkılâp olarak değerlendirmez çünkü ona göre 23 Temmuz ne saltanat rejimine, ne devletin içyapısına ne de dinî ya da dünyevî müesseselere dokunmamıştır. ${ }^{31}$ Bu noktada bir "doktrin ve kadro" adamı olan Aydemir, Genç Türkler hareketinde ne bir dünya ne bir fikirler ne de bir sistemler terkibi olmadığını, kısacası doktrini haiz bir temeli olmadıkları yönünde tenkit etmektedir. Meşrutiyet için mücadele eden zümrelerin siyasal düşünceler tarihinde yeri olan "tabii haklar", "ilahi haklar" gibi teorik tartışmalara girmediğini, fikrî derinliği olmadan sadece parlamento kurumu yani bir statü için çalıştığını bundan ötürü Genç Türkler hareketini "fikir ve doktrin mücadelesi değil”, bir "intibak" çabası olarak değerlendirilebileceğini ifade eder. ${ }^{32}$

Aydemir'e göre II. Meşrutiyet devrinde bir "kaht-1 rical” yani devlet adamı ve aydın yoksunluğu vardı ve bu durumun oluşmasında Tanzimat'tan itibaren süregelen yanlış politikaların ciddi bir mesuliyeti bulunmaktayd1 ${ }^{33}$. Gerek Tanzimat gerek II. Abdülhamit döneminde "çağın gerçekleriyle uygun" devlet adamı ve aydın yetişmemişti. ${ }^{34} 19$. yüzyıl boyunca batıya ve batı ilmine yöneliş de gelişmedi böyle olunca da 19. yüzyılın kitap ve neşriyat hazinesi

28 Şevket Süreyya Aydemir, Tek Adam I ( İstanbul: Remzi Kitabevi, 10.B, 1985), 127.

29 Aydemir'e göre Enver aşırı bir benlik gururu ve nefsine güven bulunmaktaydı. Aydemir söz konusu durumu "bu da kendinde tarihi bir misyon sezen her insanın veya her ihtiraslı emel yolcusunun tabii ruh ve karakter vasfidır" diyerek yorumlamıştır. Bk, Aydemir, Enver Paşa III, 54.

30 Şevket Süreyya Aydemir, Makedonya'dan Orta Asya 'ya Enver Paşa I (İstanbul: Remzi Kitabevi, 1970), 483.

31 Aydemir, Tek Adam I, 127.

32 Aydemir, Enver Paşa I, 287.

33 Aydemir 70'li yıllarda, Türk fikir hayatının ve aydın yoksunluğunun tarihî serencamını şu sözlerle ifade edecektir: "Türk milletinin tarihinde, fatihler, kahramanlar, devlet kurucuları, ünlü kılıç ve gazi erleri çoktur. Ama fikir adamı, idealist, ülkü arayıcısı ve hele "düşünür" yetiştirmek bakımından tarihimiz, hiç de cömert değildir. Nitekim bu vesileyle de tekrar edelim ki, biz, mesela bütün Osmanlı tarihi boyunca, gerek ihtişam, gerek çöküş devirlerimizde, herhangi bir fikir ve bilim hareketine damgasını vurup, adı yurt sınırlarını aşan, düşünce ve buluşları dünya fikriyatına katkıda bulunan tek düşünür yetiştirememişizdir”. Bk. Şevket Süreyya Aydemir, Lider ve Demagog ( İstanbul: Remzi Kitabevi, 1997), 135. Aydemir'in hatıratında ise kendisinin Tiflis'te karşılaştı̆̆ bir Tatar genci kendisine "aydın meselesi" üzerine şu çözümlemeyi yapmıştır: "Sizin tarihinizde toplumun üstünde sivrilmek için idealist olmaya bir lüzum yoktur. Sizde idealizm sadece bir vasıtadır, lüzumsuzdur... Aklı başında ve gücü kuvveti yerinde bir delikanlı İstanbul'a bir devşirme olarak mı gelir? Bir medresede fikıh, kelam mı tahsil eder? Yoksa bir savaşta mı sivrilir? Gayesi hemen bir yolunu bulup, mertebeleri hızlı hızlı geçerek sarayın, yani iktidarın kapısına çırak olmaktır... Sizde saray dışında asalet olmadığı, toprak tasarrufunda istikrar bulunmadığı, tımarlar, zeametler daima ve sarayın emri ile elden ele geçtiği için herkesi gözü, bunlardan birinin kenarına mümkün olduğu kadar sağlamca yapışmaktaydı. Bu da ancak iktidara yanaşmakla olur. Onun için sizde kendine güvenen aydın idealizmi değil, daima iktidara çıkan kolay yolu aradı". Bk. Aydemir, Suyu Arayan Adam, 187.

34 Aydemir, Enver Paşa II, 186. 
meçhul kaldı. ${ }^{35}$ İktisadî bir sistem getirmeyen Tanzimat döneminde ${ }^{36}$ eğitim hayatı da iyi tanzim edilememiş, eğitim ve kültür hayatı medreseye dayandırılmış, üniversitenin doğuşu ile gelişmesi engellenmişti. Memleket dış âleme kapalıydı bundan ötürü gelişmiş ülkelerde üniversitelere gitmek de oldukça zordu. Abdülhamit devrindeki sansür havasında ise aydından söz edilemezdi. ${ }^{37}$ Yurt dışına giden/kaçan Genç Osmanlı/ İttihatçı aydın veya "yarı aydınlar" ise doktrin değeri taşımayan, yurdun sosyo-ekonomik durumu hakkında yapılmış hiçbir tetkike dayanmayan "verimsiz" eserler verdiler. Bu bağlamda Aydemir Türk aydını ile dönemin Rus çarlığına karşı mücadele eden Rus aydınlarını mukayese ederek ${ }^{38}$ onların reformizmin her safhasına kadar doktriner ve bilimsel eserler meydana getirirken, Genç Türklerin orijinal bir eser üretememesinin "izaha muhtaç" bir konu olduğu tespitinde bulunur. ${ }^{39}$

Aydemir'e göre meşrutiyet mücadelesi bir fikir hareketine, sosyal bir cereyana dayanmadığ 1 gibi, "önder bir kütle temeline” ya da herhangi bir lidere de dayanmıyordu. Aydemir nazarında lider oldukça önemlidir çünkü lider; "herkesten daha ileriyi gören, olayları ve gelişmeleri herkesten daha doğru ve isabetli izah eden, bu güçleri ile herkesin üstünde otorite olup harekete yön tayin eden adam" demektir. Bundan ötürü, ne İttihat ve Terakki'nin kurucu nesli ne de herhangi bir bilimsel eser veremediklerini ifade ettiği Ahmet Rıza gibi Abdülhamit döneminde yurt dışında mücadele edebilenlerin hiçbirisi meşrutiyetten sonra önemli bir görev alamamıştı. Buna mukabil artık kontrol "saf idealizmi” temsil eden Selanik ve Manastır kökenli askerler oldu. ${ }^{40}$ Aydemir bu neslin saf idealizmini över ona göre 1900-1908 nesli hayatları boyunca milletin kaderine müdahale etti. Bunların idealist bir mana ihtiva eden ihtiraslarına, hayal ufuklarına sınır yoktu. Yendiler, yenildiler ana yenilgiyi hiçbir zaman kabul etmediler. Her defasında bittiği yerden başladılar. ${ }^{41}$ Buna mukabil bu nesilde "bilgisizlik", "idraksizlik"

35 Şevket Süreyya Aydemir, İhtilalin Mantığı ve 27 Mayıs İhtilali ( İstanbul: Remzi Kitabevi, 2.B,1976), 430.

36 Aydemir, Enver Paşa I, 143.

37 Aydemir, Enver Paşa, II, 186.

38 Aydemir oto-biyografisinde Çarlık dönemi Rus aydınlarından şu sözlerle bahsetmektedir: "Eski Rusya'da yetişen aydin, yalnız o memlekete mahsus bir tiptir. Kitap kurdu, derbeder, deryadil, yalnz fikir ve ihtilâl nazariyeleri münakaşalarında canl, inatçı hatta kindar..." Aydemir'e göre Türkiye'de bu tip aydının "tam mümessili" Yusuf Akçura'dır. Bk. Aydemir, Suyu Arayan Adam, 178-179. Başka bir yerde Aydemir Yusuf Akçura için şu ifadeleri kullanır: "Yusuf Akçura Türkçülük hem de şuurlu ve muvazeneli Türkçülük fikrinin hatta denebilir ki en bilimsel temsilcisi o oldu". Bk, Aydemir, Enver Paşa II, 466.

39 Aydemir, Enver Paşa I, 289. Aydemir bu hususta "bir hakikat mücahidi", "peygamberce sözlerin sahibiydi”" sifatlarıyla nitelediği Prens Sabahattin'i istisna tutar ve onun "Osmanlı davasına" bilimsel açıdan ele almak isteyen tek aydın olduğunu bu minvalde Sabahattin'in “Türkiye Nasıl Kurtulabilir” eserinin ciddiye alınması gerektiğini ifade eder. Ancak ona göre Sabahattin de memleketin tarihine, jeopolitiğine, ekonomik yapısına ve sosyal meselelerine vakıf değildi ve "Boğaziçi tepelerinden" memleket dersi vermeye çalışıyordu. Bk. Aydemir, Enver Paşa I, 272.

40 Aydemir, Enver Paşa I, 296-298.

41 Şevket Süreyya Aydemir, İkinci Adam III ( İstanbul: Remzi Kitabevi, 9.B, 2011),475-476, Aydemir, Menderes 'in Dramı, 360. Aydemir hatıratında bu "nesil" üzerine şu sözleri sarf etmiştir: 23 Temmuz 1908: "Bir inkılâp mıydı? Yoksa tarihi ömrünü tamamlamış bir imparatorluğun son çabalanışı mı? Şu bir gerçektir ki artık kuruyacak olan ulu meyve ağaçlarının son nefeslerinden önce bütün çiçeklerin açılışı ve son meyvelerini verişi gibi Osmanlı Devleti de son nefesini yaşarken, tarih sahnesine ideal ve ihtirasları sınırsız bir altın nesil verebildi. Hatta biz, bu son topraklar üstünde son devletimizi bile, bu son neslin yenilgi kabul etmeyen hayat hamlesine borçluyuz." Aydemir, Suyu Arayan Adam, 270. 
tamdi ${ }^{42}$ çünkü bu neslin formasyonları çağı, çağın akımlarını realiteler ve şartlar arasındaki bağıntıları değerlendirebilmek için gerekli olan insanlık kültürünün gelişmeleri, doktrin ve hukuk meseleleri üzerine bir şeyler okumaya müsait değildi. ${ }^{43}$

1908 ihtilâli Talat Paşa'nın gayretiyle "olağanüstü bir şöhret” bulmuştu. Bu "şöhret” “Hürriyet Kahramanı Enver Bey” olacaktı. Meşrutiyete müteakip Selanik’te Enver Bey’e büyük bir karşılama tertip eden Talat, Enver'e kırmızı ciltli bir anayasa hediye etmişti. ${ }^{44}$ Aydemir'e göre 1908 ihtilâlcilerin 1876 anayasasını getirmek dişında hiçbir fikrî temeli yoktu, ihtilâlciler savundukları anayasanın uygulanacağı devletin sosyal, ekonomik, politik problemleri ile bu temele dayandırılacak meşrutiyet üzerine bilimsel araştırma yapmamışlardı. ${ }^{45}$ Şevket Süreyya, meşrutiyetten yıllar sonra Moskova'da meşhur İttihatçı Dr. Nazım’a 1876 anayasasının ana hatlarını sorduğunda, Nazım cevaben şu sözleri ifade etmişti; "Vallahi doğrusunu isterseniz ben bu Kanun-1 Esasi’yi görmedim. İçinde ne olduğunu da hiçbir zaman öğrenemedim... Biz bir defa Kanun-1 Esasi ilan edilsin, Meclis-i Mebusan toplansın ondan sonrasinı Ahmet Riza düşünür." 46 Aydemir'e göre Ahmet Rıza gibi meşrutiyet öncesi yurt dışında olanlar ise artık "gölge" olmuştu ${ }^{47}$ buna mukabil halk da ne olduğunun farkında değildi. Meşrutiyetin ilanından sonra şehirlerde, başlıca kasabalarda halk sanki 33 yıl kapalı tutulduğu bir kafesten yahut bağlı bulunduğu zincirlerden boşanmış gibi çılgın taşkınlıklar içindeydi. Aslında ne oldu neyin değiştiği pek bilinmedi, hürriyetin, meşrutiyetin ne anlama geldiği pek anlaşılmadı. Bundan ötürü söz konusu heyecan şuurlu değildi, bir sosyal şevk gerçek bir "antuzyazm” değildi. ${ }^{48}$

Aydemir'e göre Genç Türklerin günlük siyasetçileri, günlük yazarları, gizli teşkilatçıları, komitecileri hatta "silahşörleri” vardı ama düşünürleri yoktu. Aydemir, 1908'i takip eden devrin başarısızlığında, 1908 öncesi fikri kısırlığın büyük payı ve sorumsuzluğu olduğunu zikretse de ${ }^{49}$

42 Aydemir, Enver Paşa I. 299.

43 Aydemir, Enver Paşa III, 685, Şevket Süreyya Aydemir, Tek Adam II (İstanbul: Remzi Kitabevi, 12.B, 1993 ), 237.

44 Aydemir, Enver Paşa I, 573-576.

45 Aydemir, Enver Paşa II, 54-56.

46 Aydemir, Suyu Arayan Adam, 234. Aydemir hatıratında mektep yıllarını anlatırken söz konusu bağlamda şu ifadeleri kullanmıştır: : "Bir de Kanun-1 Esasi kelimesi vardı ama halk ve hele çocuklar arasında bunu anlayan pek yoktu... Şuracıkta şu kadarını söyleyeyim ki nice yıllar sonra bu hürriyet inkılâbını memlekete getirenlerin en ileri gelenleriyle artık her şey olup bittikten ve onlar da iktidardan devrilip memleketi terk ettikten sonra görüştüklerimi ileride anlattığım zaman göreceksiniz ki, onlar da, o zaman dahi bu işlerden pek fazla bir şey anlamamışlardı". Aydemir, Aydemir, Suyu Arayan Adam, 39.

47 Aydemir, Enver Paşa I, 299.

48 Aydemir, Enver Paşa II, 46. Şevket Süreyya'nın fikirlerinde Gustave Le Bon'dan mülhem olarak kitle üzerine şüphe oldukça hâkimdir ve "yığın", "şuursuz kalabalıklar", "sürü” gibi ifadeler onun metinlerinde oldukça yaygın ifadeler olarak kullanacaktır. Nitekim eserlerinde çok fazla dipnot vermeyen Aydemir, Le Bon’un Abdullah Cevdet tarafından çevrilen “ Avrupa Harbinden Alınan Psikolocyai Dersler” eserini okuyuculara tavsiye etmiştir. Bk. Aydemir, Tek Adam I, 327. İnkılâp ve halk meselesinde ise Aydemir hatıratında şu sözleri sarf etmiştir: "Halk kalabalığı aslında inkılâbın aleyhindedir. Halkın yaptığı ve yürüttüğü bir inkılâbın tarihte misali yoktur. Halk ayaklanabilir. Örneğin Bastil'i zapt eder. Fakat bu bir inkılâp değil isyandır. Ama bu ayaklanmanın sosyal zaruretleri ve yönleri bir takım mübeşşirler ve aydın öncüler tarafından işlenmişse ve bu inkılâpçı bu hedeflere uygun bir istikamette halk hareketini gerçekleştirebilirse, bu toplumun yapısını kökünden değiştiren bir inkılâp olur". Bk. Aydemir, Suyu Arayan Adam, 373.

Aydemir, Enver Paşa I, 289. 
İttihat ve Terakki önderlerini bu handikaptan mesul tutmuştur. "Çağdaş bir siyasi kültürden" yoksun olarak nitelediği İttihat ve Terakki ${ }^{50}$, ilkel bir Balkan komitacılığının kaba sert usullerine kendini kaptırmış, ellerinde bu yüzden de sadece "komitacı ruhlu demagog" tutunabilmiştir. ${ }^{51}$ Komite iktidarında ise aydından ve devlet adamından söz edilemez. ${ }^{52}$ Hâlbuki "halkın idareye iştirak ettiği rejimlerde aydın memleketin gerçek efendisidir. Çünkü halkın iradesini gerek sınıflı toplumlarda gerek sosyal nizamın daha ileri kademesi olan sınıfsız rejimlerde aydın temsil eder. Devlet adamı ise ileri ve üstün aydın demektir çünkü siyasetin sözcüsü ve icracısı odur." ${ }^{53} 1908$ ihtilâli ise, aydınlar tarafından sistemleştirilmemiş, Abdullah Cevdet'in bile "hazmedilmediği" bu zeminde "ufku ancak Ziya Gökalp kadar olan” aydınlar sistem içinde kalabilmiştir. ${ }^{54}$ Aydemir'in nezdinde "kendine göre mütefekkir" olan Gökalp, ne bir kürsü adamıydı, ne bir teşkilatçıydı, ne de sokak kalabalıklarını peşinden sürükleyecek bir halk hatibiydi. ${ }^{55}$ Gökalp ve benzeri aydınlar yüzünden "inkılâp" inşa edilememiş ama II. Meşrutiyet nesline vatan için ölmek telkin edilmişti. Vatan için yaşamak ve onu kalkındırmak telkin edilmemişti. Bu nesle iş, inşa davaları, mülkün kalkındırılması, ülkenin iktisadî problemlerine dair bilgilerin hiçbiri verilmemişti. Vatanın inşa ve tanzim problemleri mezkûr nesil için meçhuldü. ${ }^{56}$ Mesela Balkanlar'daki isyanları İttihatçılar çözemezdi ve "Balkan faciası" kaçınılmazdı çünkü İttihatçılar meseleyi sadece askerî açıdan el alırken, bölgenin etnik durumlarına uyan reform ve idarî ıslahata giremezdi. İttihatçıların ise böyle bir reform için hiçbir planı, programı yoktu. ${ }^{57}$

Özetle Aydemir nazarında İttihatçılar ülkeyi “çürümüş, hantal, her türlü haysiyetten yoksun" bir idareden kurtarmıştı, vatanseverdi, milleti “aşağılık” duygusundan kurtarmıştı ancak yetişmiş bir aydın zümresine dayanmadıkları sadece komitacı subayların hareket ve kabiliyetlerine dayandıkları için daha ilk adımdan itibaren "inkılâp ve idealizmden" ayrılmışlardı. ${ }^{58}$ Türkiye ise 1919’dan itibaren “Millî Mücadele” verecek ve yeni kadro Mustafa Kemal Paşa'nın önderliğinde cumhuriyeti ilan ederken Aydemir'in de "hayalleri” ve "hayal kırıklıkları" devam edecekti.

50 Aydemir, Enver Paşa II, 287.

51 Aydemir, Suyu Arayan Adam, 238. Aydemir'in, "Lider ve Demagog” başlıklı kitabından da görüleceği üzere, yazınında "demagog" kelimesi menfi anlamda oldukça fazla müşahede edilen kavramlardan birisidir. Bilhassa çok partili süreci değerlerlendirirken bu kavrama fazlasıyla müracaat etmiştir. İşin ilginç tarafı ise Vâla Nureddin’ in aktarımından yola çıkarak Yalçın Küçük'ün kendisi için "demagog” ithamıyla nitelemesi olmuştur. Bk. Yalçın Küçük, Aydın Üzerine Tezler 5, 421.

52 Aydemir, Enver Paşa II, 287.

53 Aydemir,Enver Paşa II, 285.

54 Şevket Süreyya Aydemir, İkinci Adam I ( İstanbul: Remzi Kitabevi, 14.B, 2011), 331.

55 Aydemir, Enver Paşa II, 459.

56 Aydemir, Menderes'in Dramı, 69. Aydemir'in Ziya Gökalp üzerine tenkitleri, her ne kadar burada alıntılanan kadar şiddetli olmasa da, yazı hayatının çeşitli devirlerinde devam edecektir. Mesela Aydemir'e göre bilinenin aksine Atatürk, Enver Paşa kadar Ziya Gökalp'e önem vermemiş, özel konuşmalarında da Gökalp'e hayranlık duymadığını ifade etmiştir. Buna mukabil söz konusu halle Atatürk'ün Ziya Gökalp'e dair "koruyucu ilgilerine" engel olmamıştır. Bk. Aydemir, Tek Adam III, 174-175. Aydemir'in son cümlesi, kendisinin Kadro dergisinin henüz ikinci sayısında yer alan "Ziya Gökalp" yazısıyla ilintili olabilir. Bk. Şevket Süreyya Aydemir, "Ziya Gökalp”, Kadro, Şubat 1932, 29-41.

57 Aydemir, Enver Paşa II, 287.

58 Aydemir, Suyu Arayan Adam, 238. 


\section{2- Aydemir'in Tarihî Metinlerinde Atatürk Dönemine Dair Eleştiriler}

Giriş kısmında belirtildiği üzere Aydemir, TKP'den ayrıldıktan sonra kendisini Atatürk önderliğinde Türk İnkılâbına hasretmişti ve hayatının sonuna kadar da, Kemalist sıfatını kullanmayı reddetse de ${ }^{59} \mathrm{Kemalist}$ zümre dâhilinde nitelendirildi. Bundan ötürü, Aydemir'in yazınında Atatürk kuşkusuz oldukça özel bir yer taşımaktaydı. Aydemir'e göre Mustafa Kemal'in üç ana vasfı vardı: "önsezi, mantık ve meşruluk" ${ }^{60}$ Buna mukabil onun itici gücünü "ihtiras ve hayallerine sınır tanımayan, atılgan, kavgacı, mücadeleci” yönleri teşkil ediyordu. ${ }^{61}$ Millî Mücadele'ye şartlara, olaylara boyun eğmeyen, şartları ve olayları yeniden yoğurup, yeniden inşa etmeye muktedir olan, hem de "bu uğurda yalnız kellesini değil" asıl zekâsını, iradesini, ihtirasını koyan adam olarak önderlik etmişti. ${ }^{22}$ Ama bir mantık insanı olan, tarihî mantık ve tarihî mantığı seziş nitelikleri olan Atatürk ${ }^{63}$ daima "hesap ve muvazene" adamıyd1, onun için "ölüm tehlikesini göze almak ama ölmeden muvaffak" olmak önemliydi. ${ }^{64}$

Aydemir, yukarıda zikredilen "üç ana vasfın" yanına dördüncü olarak Atatürk'ün "donmuş doktrinlere bağlı olmama" ${ }^{55}$ ve aksiyon adamı olma niteliğini haiz olduğunu ifade eder. ${ }^{66}$ Atatürk "hazır doktrinlere" bağlı kalmayan, olaylara yön tayin edebilen, kalabalıkların "ensektlerine" ve gösterilerine fazla değer vermeyen, "gereğinde halka rağmen fakat halk için karar alabilen" bir inkılâpçıyd..$^{67}$ Aydemir'in yazınında "pour la peuple, malgré la peuple" sloganıyla Jacobenizmin radikal reformizmini yansıtan "halka rağmen halk için" ilkesi oldukça önemli yer tutmakta ve Atatürk'ü de mezkûr vasfindan ötürü övmektedir. Atatürk'ün 1918 yılında Karlsbad notlarında; "arzu edilen inkılâbı aniden bir coup olarak tatbik edeceğim, ben tedrici reformu kabul etmiyorum, böyle harekete karşı ruhum isyan ediyor. Neden avam mertebesine ineyim onları kendi mertebeme çıkarmam lazım" sözlerini alıntılayan Aydemir'e göre ${ }^{68}$ tek parti siyaseti halka rağmen halk içindi. Bundan ötürü inkılâpçılar halk adamı değil halk için adamlardı ve cumhuriyetin önderleri halkın kaderine müdahale etme yetkilerini seçimlerden değil, muharebelerden ve inkılâplardan aldılar. ${ }^{69}$ Mustafa Kemal kalabalıklara

59 Kemalizm kelime ve terimini yazı ve eserlerinde kullanmadığını belirten Aydemir, buna sebep olarak Mustafa Kemal hareketinin bir sistem halinde terkip ve izahının yapılmamış olması fikrinde olduğunu belirtmiştir. Bk. Aydemir, Tek Adam III, 435. Burada kuşkusuz "Kemalist" doktrin inşa etmek isteyen ve bu noktada "Kadro" hareketinin fikrî inşasında bulunan Aydemir'in kırgınlığı mevcuttur.

60 Aydemir, Tek Adam II, 270.

61 Aydemir, Ikinci Adam I, 6.

62 Aydemir, Tek Adam I, 339.

63 Aydemir, Tek Adam II, 237.

64 Aydemir, Tek Adam I, 92-93.

65 Yakup Kadri bir gün Atatürk'ün yanına gider bir inkılâp partisi olan CHP'nin ideolojiye, doktrine dayanması gerektiğini belirtir. Atatürk ise kendisine, “ o zaman donar kalırız” şeklinde yanıt vermiştir. Bk, Yakup Kadri Karaosmanoğlu, Atatürk ( İstanbul: İletişim Yayınları, 5.B,1991), 150. Bu iktibas Aydemir'in kitaplarının hemen hepsinde müteaddit defa geçer ve bir doktrin adamı olarak Aydemir bu iktibasa bazen zımnî, bazen de açık şekilde yanıt verir. Makalenin ilerleyen safhalarında konuya temas edilecektir.

66 Aydemir, Tek Adam II, 270.

67 Şevket Süreyya Aydemir, İkinci Adam III, 171.

68 Aydemir, İkinci Adam II (İstanbul: Remzi Kitabevi, 11.B, 2011), 476.

69 Aydemir, Menderes 'in Dramı, 222-224. 
"teslim olan" adam değil onları "kumanda" eden adamd1 ${ }^{70}$ ve halkın beklentileri halktan önce sezen ve halktan daha iyi bilen liderdi. ${ }^{71}$

Bütün bunların yanı sıra Mustafa Kemal "meşruiyetçidir.” Bundan ötürü onun için meclis bir nazariye değil hakikattir. ${ }^{72}$ Önce meclis sonra ordu düsturuyla, Millî Mücadelede bile kendisine "ordunun başında niye bulunmuyorsun" itirazlarına "mecliste daha önemli işler yapıyoruz" cevabı vermiştir. Bu tavır Aydemir nazarında "şarklı formasyona ve alışkanlara sahip" birisi olarak nitelediği Atatürk için "şaşırtıcı" bir batılı vizyondur" 73 ve Atatürk'ü dönemin "diktatörlerinden" ayırır zira Atatürk "biz hiçbir zaman kendimizi kanun yerine koymadık" derken, diktatörün temel özelliği sözünün ve iradesinin bizatihi kanun olmasıdır. ${ }^{74}$

Aydemir'in yazınında Atatürk döneminin "inkılâp" sürecine ise bazen zımnî bazen açık ama şiddeti yoğun tenkitler mevcuttur. Aydemir’e Atatürk ve arkadaşları Millî Mücadelede "büyük bir zafer" kazandıktan sonra yeni devleti meydana getirmişti artık "iktisadî ve sosyal Dumlupınarlar” gerekiyordu çünkü Türkiye geri kalmış, “Asyalı” bir ülkeden, uygar bir dünyada siyaseten ve iktisaden eşit bir ülke haline gelmeli, ortaçağ sınıf ve feodalite kalıntılarından temizlenmeliydi. Ancak Türkiye'nin inkılâp sürecinde "iktisadî ve sosyal Dumlupınarlar" kazanmak yolunda yapılması gerekenler "gereği kadar" yerine getirilmemişti." "75 Türkiye gibi "geri ve az gelişmiş” bir memleketin hızla kalkınabilmesi ve millî ekonomisini teşkil edebilmek için seçilecek yollar, takip edilecek usuller belirli değildi. ${ }^{76}$ İzmit mülakatında Atatürk yabanc1 sermayeye sırt çevrilmeyeceğini söylüyordu ${ }^{77}$ ve daha sonra toplanan İzmir İktisat Kongresi tam bir liberalizmi temsil ediyordu. Bu Türkiye için "geç doğmuş ve geç kalmış” bir liberalizmdi çünkü dünya artık 19. yüzyıl dünyası değildi, dünyada serbest piyasa parçalanmış, Avrupa dünyanın iktisadî merkezi olma vasfını yitirmişti. ${ }^{78}$ Yeni Türkiye liderleri hala 19. yüzyılın liberal ve ferdiyetçi batı Avrupa'sına bakıyordu. ${ }^{79} \mathrm{Bu}$ minvalde Aydemir'in en çok itiraz ettiği nokta ise 1924 Anayasası olmuştu.

Aydemir 1921 Teşkilat-1 Esasiye 'sinden sitayişle bahsederken, Millî Kurtuluş Mücadelesinin "anti-emperyalist" ve "anti-kapitalist" ruhunun bu anayasaya sirayet ettiğini ileri sürmüştü80

70 Aydemir, Mustafa Kemal'in cumhurbaşkanı olduktan sonra ilk defa İstanbul'a gidişindeki yoğun katılımlı karşılamaya müteakip yanında bulunan Hamdullah Suphi’ye; "Bunlar Vahdettin dönse onu da alkışlardı. Bu gördüğün kalabalık gün gelir, insanı linç için de böyle toplanabilir; onun sevgisine de, nefretine de fazla güvenme" dediğini aktarır. Bk. Aydemir, Menderes 'in Dramı, 262-263, 338.

71 Aydemir, Tek Adam II, 274.

72 Aydemir, Tek Adam II, 237.

73 Aydemir, Tek Adam II, 225-226.

74 Aydemir, Tek Adam III, 500. Aydemir'in dönemin diktatörlerini Atatürk ile mukayese ederken Mussolini üzerine söyledikleri oldukça ilgi çekicidir: "Mussolini bir hükümet adamıddı ama devlet adamı olamadığı için başı gitti. Ama iyi bir hükümet adamı olduğu için intizamlı çalışkanlık, getirdiği millı̂ birlik ve bütünlük duygusu, disiplinli çalışma gücü İtalya'nın mayasını teşkil etti”. Bk. Aydemir, Tek Adam III, 500.

75 Aydemir, Menderes'in Dramı, 85.

76 Aydemir, Tek Adam III, 342.

77 Aydemir, Tek Adam III, 70.

78 Aydemir, Suyu Arayan Adam, 307.

79 Aydemir, Tek Adam III, 343.

80 Aydemir, Tek Adam III, 337. 
çünkü 1921 anayasası Mustafa Kemal'in halkçılık programına dayanıyordu ve ihtilâlci bir gerekçe ile ihdas edilmişti. Anayasa Encümeninin sözcüsü İsmail Soysallığlu, bu anayasayı " tarihî ihtilâlin" bir sesi olarak algılamıştı ve anayasa "ihtilâlci bir ruh" ile birlikte inkılâpçı karakter taşıyor, "halk hareketini" derinleştirme, halka inme ve inkılâbı kökleştirmenin imkânlarını içinde saklıyordu. ${ }^{81}$ Hâlbuki 1924 anayasası "liberal” bir temele dayanıyordu ve oturmuş bir batı sisteminin anayasasıydı. Zaten Anayasa Encümeninin sözcüsü Celal Nuri, bu anayasanın Norveç’ten esinlenildiğini söylüyordu. ${ }^{82} 19$. yüzyılın ikinci yarısında olunsa ve bir sıra islahata ihtiyaç duyulsa bu tip bir anayasa kabul edilebilirdi ${ }^{83}$ oysa bu anayasanın yürürlüğe girdiği tarihte batıda bile liberalizm eleştiriliyordu. ${ }^{84}$ İstiklal Savaşı sonrasında eski bir yarı sömürge, iktisadî tesislerden yoksun, sermayesiz ilkel bir yapı vardı ve bunun kökten değiştirilmesi için yeni müesseselere ihtiyaç vardı ve yeni anayasa bunu vermeliydi. ${ }^{85}$ 1924 anayasası ise batı tipi demokrasiye yönelişin bir sonucu olarak "inkılâpçı dinamizm" ile çelişti hâlbuki ne Türk inkılâbı bir "1slahat hareketi” ne de Mustafa Kemal bir "1slahatçı" idi. Ayrıca batıdaki sömürgecilik nizamı ile sınıf mücadelelerinin beslediği Batı demokrasisi, Türk inkılâbının "tarihî zorunlulukları" itibariyle tezat halindeydi. ${ }^{86}$ Türkiye "ne batının kapitalizminden " ne de "Sovyetlerin sosyalizminden" esinlenebilecek bir yapıdaydı bundan ötürü kendi kaynaklarını "sömürge ve peyk olmadan" hızlı, zorlu, müdahaleli, planlı bir yapıyı tesis etmek için seferber etmeli ve bu yapının müesseseleri 1924 anayasasında yer almalıydı. ${ }^{87}$ 1924 Anayasası Türk İnkılâbının objektif hedefleri ve toplumun sosyal yapısı ile oldukça çekişme halindeydi ve Atatürk devrimlerini bu anayasası "zorlayarak" yapmıştı. ${ }^{88}$

Atatürk Türk demokrasinin Fransa ihtilâlinin açtığı yoldan ilham aldığını ancak kendi sosyal bünyesine uygun bir "millî inkılâp nizamı” sağladığını belirtmişti. Aydemir bu meyanda "şayet bir Türk demokrasisi” varsa bunun kendine özgü vasıflarının, prensipler manzumesi içinde belirtilmesi gerektiğini ancak bunun gerçekleşmediğini söylemek suretiyle hayıflanır. ${ }^{89}$ Mustafa Kemal, çağdaşlarının (Rusya, İtalya, Almanya, Avrupa'daki ıslahatçı sosyalistler) aksine doktrin adamı değildi ${ }^{90}$ ama Türk İnkılâbının fikrî bir yapısı vardı, inkılâp özel şartlar

81 Aydemir, İkinci Adam II, 54-59. Aydemir Yön dergisinde çıkan yazısında şu ifadeleri kullanmıştır: "Bakın Millî Mücadele ruhu, Mustafa Kemal'in, 1921'de Büyük Millet Meclisine sunduğu Teşkilatı Esasiye Kanununun Maksat ve Meslek kısmında nasıl dile getirilmiştir: "Türkiye Büyük Millet Meclisi Hükümeti, hayat ve istiklalini kurtarmayı yegâne maksat ve gaye bildiği halkı, emperyalizm ve kapitalizm tahakkümünden ve zulmünden tahlis ederek idare ve hâkimiyetinin hakiki sahibi kılmakla gayesine vasıl olacağı itikadındadır”. Bk. Şeyket Süreyya Aydemir, "Akımlar Arasında”, Yön, 31 Ekim 1962.

82 Aydemir, Ikinci Adam II, 54-59.

83 Aydemir, İkinci Adam I, 482.

84 Aydemir, İkinci Adam I, 328.

85 Aydemir, Ikkinci Adam I, 326.

86 Aydemir, İkinci Adam II, 437.

87 Aydemir, İkinci Adam I, 331.

88 Aydemir, Ikinci Adam I, 325.

89 Aydemir, İkinci Adam I, 381.

90 Aydemir, Tek Adam III,455. 
altında oluşmuştu ve bu inkılâbın esasları sistemleştirilmeliydi. ${ }^{91}$ Bu noktada Türk inkılâbının "kanuniyetlerini aydınlatmak", ilkelerini derlemek ve terkip etmek, ileri ve disiplini olan “öncü bir aydın kadronun" vazifesi idi' ${ }^{92}$ ancak Mustafa Kemal'in etrafinda hem bilinç hem de bilinçli bir heyecan yani "antuzyazm" ile bağlı "mücahit bir inanmışlar" kadrosu mevcut değildi. ${ }^{93}$

Türk inkılâbına "mücahit bir inanmış" olarak fikrî çerçeve ve aydın kadrosu inşa etmek isteyen ancak bu hedefi akamete uğrayan Kadrocu Aydemir, 6 okun 1931 yılında CHP programında, 1937 yılında da anayasaya girmesini ise önemli bulmamaktaydı. Zira ona göre Batı demokrasisine yönelen yapıda "adına devrim denilebilecek" hamlelerin yapılmasının zemini kalmamıştı. ${ }^{44}$ İnkılâpçılık, "zaten yapılış niteliği itibariyle inkılâpçı olmayan tekamülcü bir demokrasi” içerisinde anlamını yitirmiş, halkçılık ve devletçilik konuldukları ve ilan edildikleri günlerdeki manayı ya kaybetmiş ya da zedelenmişti. ${ }^{95}$ Ayrıca dönemin Ankara'sında "inkılâp ruhu" canlıydı ama inkılâp lafzı parti programına ve anayasaya girmesine rağmen az kullanılan bir sözdü çünkü inkılâp birçokları için izah ve idrak edilmemiş bir şeydi bundan ötürü inkılâpçılık "resmi” olarak benimsenemedi. Bir kısım erkâna göre inkılâp vardı ve devam ediyordu, diğer kısım erkân ise Türkiye'nin bir inkılâp yaşamış olduğunu kabul etmekle birlikte bu inkılâbın sona erdiğini düşünüyordu. Türk inkılâbının dünya ölçüsünde bir mana ihtiva etmesi düşüncesi ise herkeste bazı şüpheler uyandırıyor çünkü bu manada "uluslararasılık" seziliyor ve bundan korkuyorlardı. Bu korku ve kompleks ise "biz bize benzeriz" şeklinde formül buldu. ${ }^{96}$

Aydemir nezdinde Recep Peker partisinin 1935 kongresinde söz konusu prensiplerin "nazariyeden" değil bizzat hayattan alındığını söylerken kuşkusuz doktrin adamı olmayan Atatürk’ten esinleniyordu. ${ }^{97}$ Bundan ötürü Atatürk' ün devletçilik çabaları "aslında bir doktrin

91 Aydemir, İkinci Adam I,333.

92 Aydemir, Ikinci Adam I, 462.

93 Aydemir, Tek Adam III, 174,175. Şevket Süreyya Aydemir'in sıklıkla müracaat ettiği “antuzyazm” kavramı ve "inkılâp heyecanı" hususundaki görüşlerinin ayrıntılı bilgileri için bk. Şevket Süreyya Aydemir, "İnkılâp Heyecanı ( Antusiasm)", Kadro, Şubat 1932, 5-8.

94 Aydemir, Ikkinci Adam II, 55.

95 Aydemir, Tek Adam III,435. 1925 yılında TKP davasından yargılanan Aydemir, mahkeme sırasında "inkılâp" kelimesi müracaat ettiğinde, mahkeme başkanı Ali Çetinkaya'nın; "İnkılâp mı? Bu ne mugalata! İnkılâp bitti, bu memleket inkılâbını bitirdi" şeklinde feveran ettiğini nakleder. Oysa Aydemir'e göre inkılâp yaşamaya devam ediyordu ama "bazı insanlar bu inkılâbın önünde değil arkasından yürüyordu". Bk, Aydemir, Suyu Arayan Adam, 316.

96 Aydemir, Suyu Arayan Adam, 356. Aydemir'e göre Türk inkılâbı elbette bitmemişti. Aydemir, bu problematiği 30'lu yıllarda Kadro dergisinde kaleme aldığı İnkılâp Bitti mi” yazısında tartışıı̧tır. Bk, Şevket Süreyya Aydemir, "İnkılâp Bitti Mi?", Kadro, Mart 1932, 5-10.

97 Aydemir, Tek Adam III, 455. Aydemir 6 oka dair değerlendirmelerde genelde Recep Peker'e referans verir çünkü onlara göre Peker, Kadro hareketini bitiren ve 6 oku Kadronun prensiplerine ikame etmek isteyen kişidir. Yakup Kadri bu hususta şu sözleri sarf etmiş̧ir: "Recep Peker, "kadro" sözünden rahatsız olmuş bu ona sosyalist bir tını uyandırmış oysa bizim "kadro" hareketimiz, onun ne olduğu belirsiz 6 ok flamasından daha önemliydi çünkü esasları anlatılacaktı. Devletçilik mecliste bile anlanmadı, bunun ekonomik bir sistem olduğunu izah edemedik. Anlayanlardan bir kısmı ise monopolist, bir kısmı ise affairistlerdi bunlar devlete sırtını yaslayıp kendi menfaatlerine çalışan tiplerdi”. Bk. Yakup Kadri Karaosmanoğlu, Politikada 45 Yll, (İstanbul: İletişim Yay. 8.B, 2013), 88. 
adamı olmayan" fakat devrin akışını ve az gelişmiş bir ülkenin hızlı bir kalkınmaya ve düzenlemeye olan ihtiyaçlarını hisseden bir şahsiyetin "ruh ve fikir" yoğuruluşlarını gösterdi. ${ }^{98}$ CHP programına ve anayasaya girmesine rağmen devletçilik, bir "siyasî edebiyat" konusu olarak kalırken bir iktisadî sistem olarak devrin önde gelen politikacıları tarafından tam benimsenemedi. ${ }^{99}$ Mesela, Recep Peker 1935 kongresinde "artık liberal devletten ulusal devlete geçiyoruz" diyordu ancak mevcut 1924 anayasası liberaldi. Mahmut Esat Bozkurt, devletçiliğin "devletin ekonomik faaliyetlerde şiddetli kontrol yetkisi”, "devlet sosyalizmi" olduğunu söylüyordu fakat bu tanım Atatürk'ün Afet İnan'a dikte ettirdiği “devletçilik” mevhumuyla tamamen çelişiyordu. ${ }^{100}$ İktisadî yapının, hukukî yapıdan ayrı düşünülemeyeceğini ileri süren Aydemir'e göre mevcut anayasayla "Millî Kurtuluş Hareketine” uygun bir iktisat sistemi ya da devlet sosyalizmi inşa edilemezdi. ${ }^{101}$ Recep Peker CHP'nin 1935 kongresinde “halkçılık klişeden ibaret değildir... Türkiye'de sınıf yoktur, sınıf kavgası yoktur. Mıntıka taassubu, derebeylik, ağalık, aile, cemaat imtiyazı yoktur” sözleri ile halkçılığın prensiplerini izah etmişti ama Aydemir'e göre bu sözler de dönemin gerçeğini yansıtmamaktaydı. Halkçılık ilkesindeki idealizm toplumun gerçek yapısı ve gelişme istikametleri ile çelişiyordu ${ }^{102}$ ve "sınıfsız, kaynaşmış bir millet ülküsü” elbette uygulanamadı. ${ }^{103}$ Zira "sınıflaşmamama" ya da "sınıfsızlık" bir özlem veya soyut bir düşünce olamazdı, bunu gerçekleştirebilmek için anayasada iktisadî ilişkilerin devlet eliyle düzenlenmesini gerektiren maddelere ihtiyaç vardı. ${ }^{104}$ Özetle millet yapısını yeniden ve bütün "geri asyaî kalıntılarından” arıtarak kurtarma ülküsü ya da "tarihî zorunluluğu" yarım kalmış, mevcut çelişmeler yeni nizamı eskisinden de daha güçlü bir şekilde sarmıştı. ${ }^{105}$

Aydemir'in erken cumhuriyet döneminin sosyo-ekonomik politikalarına dair tenkitleri de oldukça şiddetli olmuştur. Aydemir'e göre cumhuriyetin kurulması, hilafetin kaldırılmasıyla inkılâp zemini tesviye edilmiş ama inkılâp ihtiyacı sona ermemişti çünkü Türkiye "ilkel bir iktisatın hiçliği”" ve "orta çağ kalıntıları" içinde yaşayan "dünkü sömürgeydi”. ${ }^{106}$ Atatürk ise toplum yapısında ve toplum düzeninde "halka rağmen" temel müdahalelere girmiş ancak inkılâptan beklediği tüm sonuçlara varamamıştı. Mesela toprak ilişkileri, iş ilişkileri, eğitim ve sağlığın toplum ölçüsünde düzenlenmesi nizam altına alınmış değildi. ${ }^{107}$ Yeni Türkiye "gerçi özgür, müstakil" olsa da, haraptı, sermayesizdi, bankacılık, demiryolları işletmeleri, dış ticaret yabancıların tekelindeydi, köylüler faizcilerin eline düşmüştü. ${ }^{108} \mathrm{Bu}$ minvalde Aydemir

\footnotetext{
98 Aydemir, Tek Adam III, 449.

99 Aydemir, Ikinci Adam I, 399.

100 Aydemir, Tek Adam III,451.

101 Aydemir, Tek Adam III, 342.

102 Aydemir, Tek Adam III, 448.

103 Aydemir, Tek Adam III, 251.

104 Aydemir, Tek Adam, 341.

105 Aydemir, İkinci Adam II, 55.

106 Aydemir, Ikinci Adam I,292.

107 Aydemir, Tek Adam III, 251.

108 Aydemir, Ikinci Adam II, 343.
} 
erken cumhuriyet döneminde demiryollarının "millîleştirilmesi" ve yeni demiryollarının devlet eliyle inşa edilmesi sürecinden ve süreci üstlenen dönemin Başbakanı İsmet İnönü’den sitayişle bahsederken, "aynı azim ve enerjinin" niçin ziraat ve köy işlerinde, doğunun "ilk çağ öncesi hayatını" tasfiye etmede kullanılmadığını sorgulamıştır. ${ }^{109}$ Hâlbuki Atatürk'ün “köylünün önemi” üzerine muhtelif atıfları vardı ancak onun köylü hususundaki direktifleri ile bu talimatların hayata geçmesi arasında ters orantı oluşmuştu. ${ }^{110}$ Köy ve ziraî siyaset alanında 1923-1938 arasında aşarın kaldırılmasından başka ${ }^{111}$ ne bir hamle ne de hangi istikametlerde nasıl yürütüleceği izah edilmiş bir tarım politikası yoktu. ${ }^{112}$ Böyle olunca da ziraî siyasette etkili, ziraî alanda olumlu netice sağlanamazken, "liberalizm bile denemeyecek bir karışıklık" içinde köy oluruna terk edilmişti. ${ }^{113}$ İşçi meselesinde de gerekli adımlar atılamamıştı. Atatürk “erbab-1 mesainin huzur ve emniyeti” şiarını ortaya koymuştu ancak dönemin iş kanunu işçinin iktisadî mücadelesinin koruyucu dayanaklarına sahip değildi. Bir zümre ve sınıf olarak işçinin haklarını meclise getirecek, savunacak sendikal bir mevzuat ya da grev hakkı yoktu. İşçinin toplu sözleşme hakkı da yoktu böyle olunca işçi ile işveren arasındaki ihtilaf işverenin lehinde sonuçlanıyordu. Bilhassa özel teşebbüslerde kadın ve kız işçilere dair "kötü muameleler" mevcuttu ve işçiler fabrikatörler, külhanbeyler ve kabadayıların insafına kalmıştı. ${ }^{114}$

Aydemir'e göre erken cumhuriyet döneminin "en hazin başarısızlı̆̆ı" bir sosyo-iktisadî mesele olarak gördüğü “doğu sorunu” politikaları olmuştur. Bu noktada dönemin Başbakanı İsmet İnönü’ye yüklenen Aydemir, doğuda yer alan Kürt isyanlarının muhtelif zamanlarda bastırıldığını ancak çözülemediğini çünkü “Kürt yoktur Türk vardır” perspektifiyle ve “inzibat ve idare” merkezli siyasetle bu sorunun bertaraf edilemeyeceğini ileri sürmüştür. Aydemir'e göre bölgede kökten bir 1slahat yapılmalı, bölgenin demografik yapısı değiştirilmeli, bölgede yer alan "cismani derebeyliği”" temsil eden ağalık ve "ruhani derebeyliğgi” temsil eden şeyhlik müesseseleri tamamen tasfiye edilmeliydi. Ayrıca bölgeye "feodal kalıntılar" yerine iskân politikasıyla göç ettirilenlerin toprak mülkiyetlerin kanunî güvencelere alınmalı, güvenlik sıkıntıları bertaraf edilmeli ve bölgede kamulaştırmalar yapılmak ve toprak dağıtılmak suretiyle küçük mülkiyet sahipliği temin edilmeliydi. Buna mukabil, sorunu "topyekûn millî dava" olarak görmeyip salt askerî ve idarî tedbirler yürüten yönetim bunların hiçbirisini başarmadı. İskân ettirilenler ise, idare-i maslahat politikalarıyla geri döndüler hatta feodal unsurlara tapu

109 Aydemir, İkinci Adam I, 366. Aydemir'e göre hiç bir dış yardım almadan yapılan demiryolları, büyük bir başarıydı. Zira cumhuriyet hükümeti eski imtiyazlı şirketlerden hatta çok yerde gişe biletçiliklerinin bile Türklere layık görülmeyerek azınlıkların çalıştırıldığı bir kadro ya da kadrosuzluk teslim almıştı. Bk. Aydemir, İkinci Adam I, 431.

110 Aydemir, Ikkinci Adam II, 301.

111 Aydemir aynı demiryolları siyasetinde olduğu üzere aşarın kaldırılmasından sitayişle bahsetmektedir. Aydemir'e göre aşar sadece iktisadî değil sosyal de bir sorundu. Aşarı toplayacak mültezim mütegallibe oluyordu. Tanzimat'tan sonra muhasıllık gelse de sorun fiiliyatta devam etmişti ve aşar kaldırıldığında köylü bile “ devlet bu vergiden nasıl mahrum kalacak, 1-2 sene sonra bu vergi geri gelir” diye düşünmüştü. Bk. Aydemir, Ikkinci Adam II,316.

112 Aydemir, Ikinci Adam II, 318.

113 Aydemir, Ikinci Adam I, 358.

114 Aydemir, İkinci Adam II, 360. 
vermek suretiyle nüfuzlarını daha da tahmin ederek "doğuyu ıslah etmek" ve "Türkleştirmek" sloganlarını yenilgiye uğrattılar. ${ }^{115}$

Aydemir, erken cumhuriyet döneminin eğitim politikalarını da eleştirmiştir. Ona göre cumhuriyet dönemi, eğitimde "teknik okullar" ve "köy enstitüleri” dişında az gelişmiş bir ülkenin ihtiyaçlarına cevap verememiştir. 1933 'te yapılan üniversite tensikatı ise esasta doğru olsa da usulde yanlış yürütülmüştür. İstanbul Üniversitesi bir Osmanlı müessesesi olarak kalmış, devrimlere ilgisiz davranmış ve "genelde muhtariyet” duvarına sığınmıştır. Medreseleri, şeriyye mahkemelerini kapatan "inkılâp önderleri” bu "muhtariyet duvarına" tahammül edemiyordu. Aydemir bu argümanlara istinaden tasfiyeyi haklı bulur ancak her ne kadar İsmet İnönü’nün tasfiye komisyonuna “ şahsi meselelerinizi karıştırmayın” demesine rağmen, Atatürk'ün Malche’ye ${ }^{116}$ müdahalesiyle de birlikte, üniversitenin yarısından fazlası işinden atılmış, bazı "çok değerli" hocalar tasfiyeden nasibini almıştı. ${ }^{117}$ Üniversitelerde "eskiliğin", geleneğin Avrupa'daki üniversitelerin "iftihar sermayesi” olduğunu dile getiren Aydemir, Türkiye'de oldukça geç oluşturulduğunu ifade ederken, medreselerin "zamana ayak uyduramayarak" üniversitelere dönüşemediğini belirtir. ${ }^{118}$ Nazi Almanya'sından gelen hocalarla birlikte ise İstanbul'da "dünya ölçüsünde bir üniversite" yapma firsatı belirmiş olsa da ${ }^{119}$, "bin bir türlü şark oyunuyla" bu hocalar kaçırılmış ve Atatürk’ün de kendi ifadesiyle üniversite deneyinde başarısız olunmuştur. ${ }^{120}$

Aydemir'in Atatürk döneminin sosyo-ekonomi politikaları ve eğitim politikalarına dair eleştirilerinde, dipnotlardan da anlaşılacağı üzere, genelde eleştiri oklarını İsmet İnönü’ye yönelttiği müşahede edilecektir. Metinlerinde Türk sağının cumhuriyet dönemi politikalarını eleştirirken, Atatürk'ü parantez dışında bırakan ve İnönü’yü hedef gösteren tarihyazımını andıran bir tutum hissedilebilir. Ancak İnönü'ye bakış açısı Türk sağından tabiatıyla farklılık gösteren Aydemir'in, Atatürk'ü zımnen de olsa tenkit ettiğini görmek mümkündür. Aydemir'e göre Atatürk "teferruatçı” bir adam değildir, devletçilik, sanayi, planlama, planlı ekonomi

115 Aydemir, İkinci Adam I, 315-319. Aydemir Doğu meselesinin serencamı hakkında şu sözleri ileri sürmüştür: "Biz doğuyu hiçbir zaman tam anlamıyla fethetmiş değildik... Tanzimat’a kadar devlet müesseseleri seyfiye, ilmiye bu gölgeye yerleşmemişti. Hep devlete mukavemet vardı, direnç halktan değil aşiretlerden geliyordu. Abdülhamit bu nizamı daha da güçlendirtmişti. Mutkili Musa gelen geçenden haraç alırdı ve biz bu adamı katılmadığ $\breve{1}_{1}$ halde Erzurum kongresinde aza yaptık!! 1925ten sonra ise ancak askerî ve idarî tedbirler oysa sorun sosyaldi... 1925-1938 arası hükümetin ağalara tutumu daima ricatli ve çelişmelidir!”. Bk.Aydemir, Ikkinci Adam II, 77-78. Aydemir hatıratında Tunceli için de şu ifadeleri kullanmıştır: "Dersim, Türkiye'nin içinde fakat Türkiye'den ayrı bir parçaydı. Haritalarda bizim görünürdü. Fakat hiçbir zaman bizim olmamıştı. Ne yol verir ne kervan geçirirdi. O da kendi ağalarının kendi şeyhlerinin elinde, kendi adetleri kendi kanunları ile dilediği gibi yaşardı. Etrafında köyler, kasabalar hem devlete hem Dersim'e vergi verirdi... Buralar güya bizimdi ve düşman henüz uzaktaydı". Bk. Aydemir, Suyu Arayan Adam, 75.

116 Atatürk tarafından Türkiye’ye davet edilen İsviçreli pedagog Malche, üniversite reformu için görevlendirilmiştir. 1933 üniversite tensikatı için bk. Horst Widmann, Atatürk ve Üniversite Reformu, çev. Aykut Kazancigil- Serpil Bozkurt ( İstanbul: Kabalcı Yayınevi, İstanbul, 1999).

117 Aydemir, Ikkinci Adam II, 372-375.

118 Aydemir, Ihtilalin Mantığı, 428-429.

119 Aydemir, Ikinci Adam II, .376.

120 Aydemir, Ihtilalin Mantığ, 429. 
gibi konularda "sadece yukardan nezaret eden bir adamdır", meselenin teferruatı ile hiç ilgilenmemiştir. ${ }^{121}$ Atatürk bir aksiyon adamıydı ve inkılâpçılık onun mümeyyiz vasfıydı, o hiçbir zaman hükümet ya da büro insanı olmamıştı. Zaten hükümetçilik "inkılâpçı bir aksiyon değil" bir icra işidir ve hükümetçi ancak "inkılâbın emrinde olarak" inkılâbın kanunlarını yürütecek bir fonksiyonu ifa eder. Bu minvalde inkılâpçı Atatürk’ün hükümetçisi İsmet İnönü oldu ve Atatürk bir hükümet adamı gibi icranın günlük işleri ile ilgilenmedi. ${ }^{122}$

İcranın günlük işleri ile ilgilenmeyen Atatürk 1930'lu yıllarda, “aktif hayat çarklarından, devlet meseleleri çatışmalarından" gittikçe çekilmiş, halkın ona biçtiği "efsane kahraman libası"123 ve büründüğü "resmi heybet" içinde gittikçe kendi içine gömülmüştü. ${ }^{24}$ Böyle olunca "yeni nizamın dinamizmi” Atatürk'ün sağlığında, hele onun son yıllarında, hem fikrî alanda hem de aksiyon alanında hızından çok şeyler kaybetmişti. ${ }^{125}$ Serbest Cumhuriyet Partisi tecrübesi göstermişti ki, hükümet halkı ihmal etmişti ${ }^{126}$ ve Atatürk partisinin halk nezdindeki durumu hakkında yeteri kadar bilgi sahibi değildi. ${ }^{127}$ Memleket "nice Derviş Mehmetler" yetiştirme istidadındaydı çünkü sosyal yapı değişmemişti, şehir ve kasabalarda irtica "teneffüs alanı" buluyordu. CHP ise "dinamik gençler, inkılâpçı aydınlarla" değil bürokratlar ve mahalli menfaat gruplarıyla teşkilatlanıyordu. ${ }^{128}$ Atatürk halk ile temasını kesmiş ${ }^{129}$, kendisini "bütün ihtirasıyla birlikte" yarı akademik çalışmalara vermişti yani aksiyondan çıkıp "verimsiz bir masa başı" işine girişmişti. ${ }^{130}$

\section{3- Aydemir'in Tarihî Metinlerinde İnönü Dönemi Eleştirileri}

Atatürk’ten sonra cumhurbaşkanı olan İsmet İnönü, Aydemir'in nitelemesiyle "İkinci Adamdır.” Aydemir'e göre İnönü gerçek bir savaşçıydı, kendisine bir gün; "Savaş kumandanın

121 Aydemir, Tek Adam III, 372.

122 Aydemir, İkinci Adam I, 120. Erken cumhuriyet döneminin öncülerinin rollerinin analiz edildiği bu iktibasta Aydemir, "bürokrat" zihniyeti açıkça eleştirmese de eserlerinin birçok yerinde bürokrat zihniyet ile inkılâbın uyuşmadığını dile getirir. Mesela 1924 anayasasını eleştirirken şu ifadeleri kullanmıştır; "Devrim sona ermemişti ancak bu anayasa Bab-1 Ali kokuyordu. Hükümet bürokrat düzende kuruldu ve bürokrasi devrimin dinamizmini yendi. Klasik manada demokraside çoğunluğun oyu önemlidir oysa devrim azınlığın iradesinin çoğunluğun iradesine hâkim olması demektir.” Bk. Aydemir, İkinci Adam II, 55.

123 "Mustafa Kemal artık fevkelbeşerdi, o bundan memnun muydu hem evet hem hayır, halk çünkü tarih sevmez, destan sever ve bu destanın kahramanı oydu, kahraman artık bir daha hareket noktasına dönemez”. Bk. Aydemir, İkinci Adam I, 272.

124 Aydemir, Tek Adam III, 372.

125 Aydemir, Ikinci Adam II, 51.

126 Aydemir, Tek Adam III, 393.

127 Aydemir, Tek Adam III, 390.

128 Aydemir, Tek Adam III, 394.

129 Aydemir, Tek Adam III, 379.

130 Aydemir, Tek Adam III,539. Aydemir burada 30'lu yılların dil ve tarih alanında yapılan reformları işaret etmektedir. Aydemir hatıratında dil ve tarih alanındaki tezlere, Atatürk'ün "asil bir ilim hasreti” olarak nitelemesine rağmen müstehzi yaklaşmıştır. Aydemir'e göre Atatürk de aslında bu tezlerin farkındaydı ama "tarih içindeki bütün yüz milyonlarla bir satranç tahtasındaki gibi” oynuyordu diyerek ekler: "Bunda bizim bilmediğimiz, bizim anlamadığımız, hatta bizden sakladığı bir sır, bir zevk, bir ruh tatmini olsa gerekir”. Aydemir, Suyu Arayan Adam,370. 
kafasında kaybolmadıkça, yenilgi tamamlanmış ve savaş sona ermiş değildir. Millî Mücadelede biz bu savaşı, hiçbir zaman kafamızda kaybetmiş duruma düşmedik"131 sözlerini sarf etmişti. Buna mukabil İnönü, "nizam dışı" hareketlerin coşkun bir öncüsü ve "heyecan adamı" değildi. ${ }^{132}$ "Kendisini kolayından ortaya atmayan”, kavga ve mücadeleye "kesin kazanılacağını" düşündüğü anda giren bir adamı bundan ötürü onun hayatında ne Enver'in çete maceraları ya da Atatürk'ün Libya direnişi gibi tecrübeler yoktu, o harita ve pergelle silahtan daha yakın arkadaştı. ${ }^{133}$ Uyumlu birisi olduğu için Enver ${ }^{134}$ gibi "sert, tartışma kabul etmez, kapalı" karakterde birisinin yanında çalışabilirken, Atatürk ve Karabekir gibi Alman askerî otoritesi ile çatışmaya girmemiş hatta Alman komutanlar kendi aralarında ihtilafa düştüklerinde, Enver Paşa tarafından uzlaştırmak için görevlendirilmişti. ${ }^{135}$ Hükümet adamı olan İnönü, Atatürk gibi doktrin adamı olmamış, hayatı boyunca doktriner işlerle uğraşmamıştı. ${ }^{136}$ Cumhurbaşkanı İnönü ise hiçbir zaman “topyekûn hamlenin" adamı olmamış, adına hükümet denilen, dokunulmaz bir hiyerarşi düzeni olan statik nizamın içinde kalmış, her daim klasik mevzuatı, dalgalar yaratacak müdahalelere tercih etmişti. Bundan ötürü ıslahatı da "ancak dar çerçevede alan” şekilci ve tekamülcü bir cumhurbaşkanı olmuştu. ${ }^{137}$

Aydemir'e göre İnönü döneminin en önemli misyonu “Atatürk'ü ikmal etme” idi. Bu dönemde Atatürk'ün sadece devamı değil "tamamlanması" lazım geliyordu. Bir doktrin adamı olmayan İnönü' den elbette doktrincilik beklenemezdi ama toprak devrimi gerçekleştirilebilir, sınıf hâkimiyetine, oligarşi sömürgeciliğine, eşraf-ayan türediliğine son verilebilirdi. Devletçilik genişletilerek büyük tesisler yaratılabilir ve klasik manada bir kapitalizme ve sınıf kavgalarına meydan verilmeyebilirdi. Laiklik derinleştirilebilir, "batıdan kopya eğitim” yerine devrimci bir eğitim uygulanabilirdi. Atatürk döneminde köylüye "dokunulmamıştı", doğudaki sosyoekonomik problemleri ise devam ediyordu. Bundan ötürü "millî şef” nizamı ile halkçı, laik, inkılâpçı özetle müdahaleci bir "millî cumhuriyet" tesis edilmeli, inkılâp dinamizmi sağlanmalıydı ${ }^{138}$ Aydemir burada İnönü döneminden beklentilerini aktarırken esasında İnönü dönemi eleştirilerini en baştan tasnif ediyordu. Tenkitleri de beklentileri ile mütenasip olacaktı.

İnönü'nün cumhurbaşkanlığının ilk yılları, II. Dünya Savaşı'nın başlamasına tesadüf etti. Aydemir yazınında, İnönü'nün Türkiye'yi savaş dışı bırakmasından büyük bir övgüyle

131 Aydemir, Tek Adam II, 484.

132 Aydemir, Tek Adam III, 102.

133 Aydemir, İkinci Adam I, 6.

134 Aydemir, Enver Paşa'yı överken bazen İsmet İnönü’ye de müracaat eder. Mesela İnönü’nün Enver Paşa için; “ şahsi meziyetleri ile iyi bir asker, iyi bir subay, iyi bir insan olarak toplumun kusur olarak bildiği unsurlardan insanın tasavvur edemeyeceği kadar nasibi olmayan bir tiptir. Asker vasıfları bakımından vazife sever, çalışkan ve korku nedir bilmez. Müstesna kahraman olarak askerliğin aradığı ölçülerin en yukarı seviyesinde yer almıştır”. Sözlerini aktarmıştır. Bk. Aydemir, Enver Paşa III, 71.

135 Aydemir, Tek Adam III, 102.

136 Aydemir, Ikinci Adam I, 393.

137 Aydemir, Ikinci Adam II, 224-225.

138 Aydemir, İkinci Adam II, 54-59. 
bahsetti. ${ }^{139}$ Buna mukabil Aydemir, Türkiye'nin II. Dünya Savaşı sürecindeki bazı politikaları tenkit etmekten imtina etmedi. Aydemir'e göre II. Dünya Savaşı Türkiye için iktisaden “çok elverişsiz" bir zaman tesadüf etmişti. Atatürk döneminden tevarüs eden idarî ve ekonomik yapı çok zayıftı ve "enerji ile teşkilat bütünlüğü" isteyen hallerde mevcut yapının "ilkelliğì" tezahür ediyordu. ${ }^{140}$ Türkiye'nin dövizi yetersiz, dış yardım ve istikrazları kabil olmayan, fakir ve ziraî alanda sermaye birikmesi göstermeyen bir iktisadî yapıyı haizdi. ${ }^{141} \mathrm{Bu}$ olumsuz şartlarla birlikte, II. Dünya Savaşı öncesinde şartlar artık cephe veya cephe arkası bölüntülerini kaldırmış, "topyekûn harp sistemi" gelmişti. ${ }^{142}$ Devletin "siyasî, askerî, ekonomik, moral" bütün kaynaklarının savaşa kanalize olmasına işaret eden "topyekûn harp" hazırlığı savaş öncesi barış dönemlerinde yapılırdı ancak Türkiye' de "ne hükümet ne de aydınlar ne de ordu" I. Dünya Savaşından sonra oluşan harp kavramları ve harp ekonomisi bilgilerini haiz değillerdi. Bundan ötürü II. Dünya Savaşı esnasında seferberlik hazırlıkları I. Dünya Savaşı seviyesindeyken, "topyekûn harp" perspektifli bir örgütlenme söz konusu olmad1. ${ }^{143}$ Her ne kadar Refik Saydam gibi “a dan z ye her şeyi değiştireceğiz” diyen Başbakanlar olduysa da bu sözler "zaruretleri" harekete geçiriyor ama "imkânları" harekete geçirmiyordu. ${ }^{144}$ Mesela İnönü’nün Ticaret Bakanı Behçet Uz "iktisadî bir anarşi” getirmiş ${ }^{145}$, fiyatlar üzerindeki murakabeyi kaldırmıştı bu durum mesela buğdayın bir anda 10 kat pahalanmasına sebebiyet vermişti. ${ }^{146} 1908$ tipi iktisadî hürriyet savaş şartları ile birlikte fiyat spekülasyonunu getirmiş, memlekette yeni hacıağaların" türemesine ve kontrolsüz dalgalanmalara zemin hazırlamıştı. ${ }^{147}$ Çok tartışılan "varlık vergisi" zaruriydi ama verginin çıkartılmasına mezkûr olumsuzluklar neden olmuştu. ${ }^{148}$ Aydemir II. Dünya Savaşı esnasında çıkarılan ve çok tartışılan bir diğer uygulama olan "Millî Korunma” kanunu da desteklemiş ancak kanunun mevcut anayasa ile çelişkili olduğunu, anayasanın serbest tedarike, satış haklarına ve mülkiyet haklarına devletin

139 Aydemir'e göre Türk hükümetinin izleyebileceği tek yol, kendi kabuğu içinde vaziyet almak ve savaş dışı kalmanın çarelerini aramaktı. İnönü zekâsı ile bunu başardı. Bk. Aydemir, İkinci Adam, 135.

140 Aydemir, İkinci Adam II, 201.

141 Aydemir, İkinci Adam II, 132.

142 Aydemir, Ikinci Adam II, 72.

143 Aydemir, Ikinci Adam II, 203-208. Aydemir bu meseleyle şahsen ilgilenerek ilgili makamlara raporlar yazdığını ancak raporların bürokratik engele takıldığını ifade ederek şu sözleri sarf eder: "Geri ve örgütsüz ülkede bu alanda başvurulmak istenen zorunlu tedbirler de daima bürokrasinin duvarlarına vurarak yıpratılmış ve tesirsizleştirilmiştir... Atatürk devrinin de geçmiş olmasına rağmen biz henüz Osmanlı çöküntüsünün kalıntıları üstünde çalışıyorduk, gerilik ve bürokrasinin pis tortularından temizlenmiş değildik!’. Bk. Aydemir, İkinci Adam II, 72 .

144 Aydemir, Ikkinci Adam II, 224.

145 Aydemir, İkinci Adam II,344.

146 Aydemir, İkinci Adam II, 224.

147 Aydemir, Ikkinci Adam II, 229-230.

148 Aydemir, İkinci Adam II, 229. Aydemir, Varlık Vergisi mükellefi Musevi asıllı Avram Galanti ile bu konuda tartışırken şu ifadeleri kullanmıştır. "Bizim asırlarca dökülen kanımızla, sizin bu sefer vereceğiniz iki yüz milyon kağıt liralık varlık vergisini karşılaştırırsak ve buna hatta bir 'kan vergisi' desek, hesaplaşmamız acaba çok zalimane olur mu... Sizin şu bir avuç vergi fazlanızı karşılaştıracağımıza, sizin biriken servetlerinizle, bizim biriken kan ve askerlik haklarımızı teraziye koyarak hesaplaşalım. Eğer biz haksız çıkarsak, vergileriniz silinsin”. Bk. Aydemir, İkinci Adam II,236. 
müdahalesine karşı olduğunu dile getirmişti. ${ }^{149}$ Burada kuşkusuz Aydemir'in tenkit ettiği husus, devlet müdahalesi değil 1924 anayasasının söz konusu niteliği olmuştu.

Atatürk dönemi ziraat politikalarını eleştiren Aydemir, İsmet İnönü’nün de cumhurbaşkanlığı sürecindeki tarım siyasetini tenkit etmiştir. Aydemir'e göre ziraî mesele millî bir meseledir, onu rejim davasından ayırmak mümkün değildir ancak Türk İnkılâbı sürecinde köy, köylü, ziraî yapı meseleleri hiçbir zaman "ne düşünürünü ne de hareket adamını” bulmuştu. İnönü "ne inkılâpçı ne de ıslahatçı" zaviyeden dokunulmamış bir köy mirası almıştı; yorgun bir toprak, ilkel bir ziraî yapı, kaybedilen ormanlar, kötü kullanılan meralar, toprak üstünde ağalık gibi sorunlar mevcuttu. Devrimin köye girmesi için köyün sosyal yapısında inkılâpçı müdahalelerle, inkılâpçı bir düzen uygulanmalıydı, ağalık, beylik, faizci olduğu müddetçe üst yapıda ne kadar değişiklik olursa olsun, inkılâbın köye sirayet etmesi beklenemezdi. ${ }^{150}$ Ancak Aydemir'e göre Atatürk'ün Başbakanı iken ziraî alanda başarılı olamayan İnönü, "millî şefliğgi” döneminde de başarısız olmuştu. Köylü sermaye birikmesi sağlayamamış, yanlış fiyatlarla "beli bükülmüştü”. ${ }^{151}$ Bununla birlikte esas sorun "toprak reformu" meselesi idi.

Aydemir'e göre 1923-1950 arası dönem toprak kanunu açısından "hazin bir başarısızlık" örneği olmuştu. ${ }^{152}$ Meclis toprak kanununa daima şüphe ile bakmış ${ }^{153}$, toprak reformu söz konusu olduğunda, hemen "Bolşeviklik" ithamı ile reaksiyon vermişti. ${ }^{154}$ Ancak nasıl ki tek parti rejimi hilafetin kaldırılması, alfabe reformu gibi meselelerde "olağanüstü" yetkilerini kullandıysa, toprak meselesinde de kullanmalıydı. Mecliste toprak reformuna muhalefet vard1 ama tek parti rejimi de bunun için vardı. Sarıklı hocalar şapka inkılâbını nasıl alkışlamışsa, meclistekiler de toprak reformunu alkışlamak zorunda kalacaktı. Bu meselenin müsebbibi Atatürk ve İnönü'nün doktrin adamı olmayışından ötürü partinin ideolojisini düzenlemeyerek inkılâpçı bir öncü kadro yetiştirmemesi oldu. ${ }^{155}$ Aydemir bu hususta dönemin Tarım Bakanı Şevket Raşit Hatipoğlu'nu müstesna görmekteydi. Ona göre Hatipoğlu, toprak meselesini ciddiye alıp meseleye ilmî zaviyeden bakan ender kişilerdendi. ${ }^{156}$ Ancak onun hazırlanmasında oldukça emeği olduğu, dönemin çok tartışılan ve mecliste başka bir partinin doğuşunu işaret edecek olan "Çiftçiyi Topraklandırma Kanunu" ölü doğan bir yasayd1. ${ }^{157}$ Meclisin çoğunluğu tasarının aleyhindeyken, topraklandırma komisyonunda hükümet azınlıktaydı ${ }^{158}$ ve kanun çıktıktan hemen sonra muhalefet zaten ölü doğmuş yasayı tadil etmeye çalıştı. Hâlbuki 19231924 döneminde olduğu gibi parti "şef” isterse ve biraz da isteğini "dikta” haline getirirse,

149 Aydemir, Ikinci Adam II, 214.

150 Aydemir, Ikinci Adam II, 60-63.

151 Aydemir, Menderes'in Dramı, 117.

152 Aydemir, Ikinci Adam II, 338.

153 Aydemir, Ikinci Adam II, 329.

154 Aydemir, Ikkinci Adam II, 347.

155 Aydemir, Ikkinci Adam II, 352-354.

156 Aydemir, Ikinci Adam II, 334.

157 Aydemir, Íkinci Adam II, 350.

158 Aydemir, Menderes 'in Dramı, 127. 
gereğini yapardı ama artık şef o dönemdeki gücünde değildi. ${ }^{159}$ Aksine İnönü “idealist” Tarım Bakanı Hatipoğlu yerine tasarıya muhalefet eden toprak ağası Cavit Oral'ı bakan atamadı ve yeni bakanlar birlikte kanunu "işlemez" hale getirecek değişiklikler gerçekleşti. ${ }^{160} \mathrm{Bu}$ değişikliği "ricat" olarak değerlendiren Aydemir, müstakbel bir seçimde toprak ağalarının ve onların emrindeki kalabalıklarının oyları üzerinde bir kaygıya işaret ederek 161 "bürokrat ve oportünist" zihniyetin, inkılâpçı karar adamlarını yendiğini ${ }^{162}$ ve CHP'nin 1945 yılında toprak reformu bakımından "büyük imkanları" kaybettiğini düşünmekteydi. ${ }^{163}$

1945 yılı Modern Türkiye tarihi açısından önemliydi zira "çok partili hayata dönüşün"164 adımları atılmıştı. İsmet İnönü 19 Mayıs 1945 nutkunda, cumhuriyet rejiminde bulunan siyasi sistemle halk hükümetinin her bakımdan gelişeceğini ve siyasi/kültürel hayatta demokrasi ilkelerinin daha fazla yer tutacağının taahhüdünü vermişti. ${ }^{165}$ Nutkun hemen akabinde CHP içerisinden Celal Bayar, Adnan Menderes, Fuat Köprülü ve Refik Koraltan “dörtlü takrir" vererek siyasi hakların ve halk idaresinin önündeki sınırlayan engellerin ortadan kalkmasını talep etti. Talep reddedildi ancak daha önce toprak reformu ile başlayan ve dörtlü takrir ile tebarüz eden parti için muhalefet, istifalar ya da ihraçlar yoluyla farklı bir siyasî partinin doğuşuna zemin hazırladı.

"Çok partili rejim, başlı başına, ne iyidir, ne de fenadır” diye düşünen Aydemir"166 ise demokratikleşmenin zamanlamasını şu sözlerle doğru bulmuyordu. "Açıkça söylemek gerekirse 1945 'te çok parti sistemine geçmek işini daha sonraya bırakarak çok cepheli ve topyekûn bir inşa işine geçebilseydi, başlayan dış yardımlar ve millî enerji seferber edilseydi, biz bugünkü sosyal-politik-ekonomik çelişme ve çatışmalara düşmeyebilirdik. Yani çok partili sisteme geçiş, bir devre daha bekleyebilirdi." ${ }^{167}$ Batı anlamında demokratik bir seçime gitmek, bunun için yeni seçim kanunları getirmek, "kalabalıkların ve oy çoğunluğunun hürriyet ve hâkimiyetini" müjdelemiş ve "aşırı bir demokrasiye" yol açmıştı. ${ }^{168}$ İnkılâpları hoş görmeyen ama sesini çıkaramayanlar artık reaksiyon gösterecek, II. Dünya Savaşı'nın vergileri sorulacaktı. Artık “Nurcular, Ticaniler" sahnedeydi ve ağalar, şeyhler "cihada gider gibi” sandığa gidecekti. ${ }^{169}$ Kimse İsmet Paşa'nın Türkiye'yi savaş dışı bırakmasındaki “insanüstü başarısına” bakmazdı

\footnotetext{
159 Aydemir, İkinci Adam II, 354.

160 Aydemir, İkinci Adam II,350. İnönü, dönemin Başbakanı Şükrü Saraçoğlu’nun, Hatipoğlu yerine toprak reformuna muhalefet eden Adnan Menderes'i bakan yapmayı düşündüğünü söylemiştir. Bk, Aydemir, Menderes 'in Dramı,117.

161 Aydemir, İkinci Adam II, 350.

162 Aydemir, Ikinci Adam II, 354.

163 Aydemir, Menderes'in Dramı, 129.

1641908 yılında II. Meşrutiyetle açılan mecliste "çok partili” hayat mevcuttu ayrıca kısa süreli de olsa cumhuriyet döneminde farklı siyasi partiler kurulabildi. Bundan ötürü "çok partili hayata geçiş” yerine "çok partili hayata dönüş" ibaresi tarihi gerçekliğe daha uygun görünmektedir.

165 Kemal Karpat, Türk Demokrasi Tarihi (İstanbul: Timaş Yay. 2010), 229-230.

166 Şevket Süreyya Aydemir, Lider ve Demagog, 14.

167 Aydemir, Menderes 'in Dramı, 344.

168 Aydemir, İkinci Adam III, 16.

169 Aydemir, Ikkinci Adam II, 480.
} 
hatta bu başarı unutulmuştu çünkü bunu değerlendirmek bir "akıl işiydi” ve kalabalıklar "akıl ölçüsünden" anlamazlard1. ${ }^{170}$

Aydemir “demokrasiye geçiş” hususunda İnönü’nün kararının sebebini de sorgulamaktaydı. Aydemir, İnönü’nün 1944 yılında taklit olmayan, kendi bünyesine uygun olan birlik ve beraberliği misyon edinen "Türk tipi demokrasi” vurgularını gündeme getirirken, klasik demokrasinin "birlik ve beraberliğe" değil murakabe sistemine dayandığını bundan ise batı tipi bir demokrasi çıkarılamayacağını savundu. ${ }^{171}$ "Millî Şef” sisteminin olduğu yerde İnönü’nün yakın çevresinin ${ }^{172}$ "Paşa hep çok partili nizamı istiyordu" sözlerine itibar edilemezdi. ${ }^{173} \mathrm{Bu}$ minvalde Aydemir, İnönü’nün bu kararını ne dış mihrak, ne II. Dünya Savaşı koşulları ne de Demokrat Partiyi kuracak olan vekillerin muhalefeti ile tahlil etmişti. ${ }^{174}$ Aydemir'e göre eğer 1945 'te çok partili hayata geçmeseydi de bu yol açılacaktı çünkü 1924 anayasası bir inkılâp anayasası değil, liberal bir anayasaydı ve tadillere rağmen bu yapı klasik batı nizamına gitmeye yol açacak, kapitalist düzen de hâkim olacaktı. ${ }^{175}$ Mevcut sistem "ne demokrasi ne de diktatörlüktü”, tek partili otoriter bir rejim mevcuttu. ${ }^{176}$ İnkılâp, Atatürk'ün mevcudiyeti ve İnönü’nün hükümetçiliği ile yürüyordu ama rejimin "presendentielle” özelliğine rağmen bu iki liderin de ruhunda "Batı ne dair bir nizam" özlemi vardı. ${ }^{177}$

Neticede "halk kalabalıkları” oy meydanına çağrılınca İnönü yenilgiye uğradı. Aydemir'e göre Atatürk de aynı durumla karşılaşabilirdi. ${ }^{178}$ Çanlar DP için çalıyordu, bunda halk psikolojisinin çeşitli ruhi etkileri vardı. Yıllardan beri "geri itilen, unutuldu sanılanlar”, çeşitli refulmanlar harekete geldi. ${ }^{179}$ Buna mukabil İnönü ile CHP “yorgundu” ve ink1lâp hamlesiyle gelen rejimlerde yorgunluk, inkılâpçı iktidarın sonu demekti. İktidar kendi varlığının hikmeti

170 Aydemir, İkinci Adam II, 397. Daha önce de zikredildiği üzere, Aydemir'in Le Bon'dan mülhem kitleye bakış1 düşüncelerine sirayet etmiştir. Aydemir'e göre çok partili nizamda halk kalabalıklarının oyları ve bu oylarda bu kalabalıkların yıllar yılı geriye itilmiş, halk ruhunun derinliklerinde birikmiş "bin bir ilkel duyguları", istekleri, eğilimleri olacaktı. Kalabalıklar meydanında ise demogog, karşısına çıkacak akıl ve mantık adamını her zaman yenebilirdi. Bk. Aydemir, İkinci Adam III, 83. Aydemir ayrıca Platon'dan mülhem olarak seçkinci bir demokrasi anlayışına sahipti. Zaten kendisi de Platon'dan iktibaslar yaparak halkın eğitimli olmadığı toplumlarda demokrasinin "otokrasiye" dönüşeceğini ve Türkiye tecrübesinin de bunu doğruladığını ileri sürmüştür. Bk. Aydemir, İkinci Adam II,432.

171 Aydemir, Ikinci Adam II,434.

172 Aydemir İnönü’nün karakterini tasvir ederken şu sözleri sarf etmiştir. “İnönü’nün yakın arkadaşı olmaz sadece yakın çevresi olur çünkü yakın arkadaşlık ruhi bir angajmandır ve bu İnönü’de olmaz. İnönü partinin başında hancı gibidir gelene ağam gidene paşam, ama hanı terk etmez adam DP'ye gider, Hürriyet Partisine gider ama gelene yine hoş geldin der”. Bk. Aydemir, İkinci Adam II,.428. İnönü, Atatürk’e bile angaje olmayan, kendini bütünüyle vermeyen bir şahsiyetti. Bk. Aydemir, Menderes 'in Dramı, 264-265.

173 Aydemir, İkinci Adam II,429.

174 Söz konusu tahliller ve değerlendirmesi için bk. Asım Karaömerlioğlu, “Türkiye’de Çok Partili Hayata Dönüşün Toplumsal Dinamikleri”, Toplum ve Bilim, 1 Ocak 2006, 174-191.

175 Aydemir, Ikinci Adam II, 426.

176 Aydemir, Ikkinci Adam II, 434.

177 Aydemir, Ikinci Adam II, 426.

178 Aydemir, Íkinci Adam II, 430.

179 Aydemir, Ikkinci Adam II, 480. 
olan dava ve sloganlarından kopmuştu. ${ }^{180} \mathrm{CHP}$ bir siyasî rejim getirmişti ama iktisadî bir dava getirememişti. ${ }^{181} 1923$ 'ten itibaren genel bir "kalkınma problemi”" vardı ve "çağa uygun bir hız" alınamamışt. ${ }^{182}$ Bundan ötürü çok partili dönemde bir "iktisadî Ergenekon" havası estirilmeli, ekonomik hamleler hayata geçmeliydi. ${ }^{183}$ Bunlar gerçekleşmeyince Demokrat Parti iktidarı da mukadder oldu.

\section{4- Aydemir'in Tarihî Metinlerinde Menderes/Demokrat Parti Dönemi Eleştirileri}

İnönü'nün iktidardan devrilmesiyle Aydemir'in "kahramanlar devri” olarak nitelediği dönem sona ermişti. ${ }^{184}$ Zaten Aydemir' in nezdinde demokrasi bir kahramanlar rejimi değildir. Kahramanları, ihtilâl ve inkılâp devirleri verir. ${ }^{185}$ Adnan Menderes ise "kahramanlar devrinden sonranın" tipik bir temsilcisi oldu, kendisinde selefleri gibi harp meydanlarından değil parlamento yollarından gelmişti. Buna mukabil Menderes bir mücadele adamıydı ve kendi ölçüleriyle "başka bir ihtirasın öncüsü” olarak kahramanlar devrinin anti-tezini teşkil etti. ${ }^{186}$ Menderes idealist bir adamdı ve en önemli iki özelliği kendine güvenmek ve halka dayanmak ihtiyacı idi. ${ }^{187}$ Siyaseti halka mal etmeyi başarmış, şehirde, kasabada siyaseti yayarak halkta bir nevi "şahsiyetleşmenin”, şahsiyet gururunun yerleşmesine hizmet etmişti. ${ }^{188}$ Menderes "toprak adamıydı" ve köyde ziraî bir kalkınma gerçekleştiremeyen CHP yerine, halk nezdinde "toprağ tanıyan adam" olarak "beklenen adam" hüviyetindeydi. ${ }^{189}$ Devlet hizmetinden gelmemesi, İnönü’nün aksine bürokratik çarklara bağlılık ve bunların engellemelerine karşı "daha geniş bir karar serbestisi" sağlamıştı ancak bu özelliği onun sadece günlük icraatlarında değil "kader ve akıbetinde" de etkili olmuştu. ${ }^{190}$ Menderes hep tek söz sahibi olmuş ancak "tek adam" olamamıştır ki çok partili nizamda da tek adam değil halk adamı gerekir. Ancak Menderes

180 Aydemir, İkinci Adam II, 393. "Bu yorgun ve kararsız iktidar, İkinci Dünya Harbi sonunda gene de büyük bir karar verebildi...Çünkü artık yapacağı başka şey kalmamıştı...Kanaatim hem de bir eski Halk Partili olarak şudur ki, iktidar eğer 1946’da değişseydi, çok daha iyi olurdu”. Bk, Aydemir, Suyu Arayan Adam, 391.

181 Aydemir, İkinci Adam II, 486.

182 Aydemir, Ikinci Adam II, 396.

183 Aydemir, Ikinci Adam II, 395.

184 Aydemir, İkinci Adam III,593. "Kahramanlar devri, artık sona ermişti. Ve çok partili rejim çıkış yolu sanılıyordu. O halde, Halk Partisi de, Şef Partisi olmaktan, artık Halk Partisi olmaya koymalıydı. Çünkü Atatürk devam ettirilememişti. Atatürk ikmal edilememişti. Tek şef, tek parti, otoriter devlet sistemi de böylece, artık yürüyemezdi. Millî Şef, değişmez başkan kavramı artık havadaydı”. Bk. Şevket Süreyya Aydemir, Kırmızı Mektuplar Son Yazıları ( İstanbul: Çağdaş Yay. 1979), 137.

185 Aydemir, Lider ve Demagog, 101.

186 Aydemir, İkinci Adam III, 59.

187 Aydemir, Menderes 'in Dramı, 182.

188 Aydemir, Menderes 'in Dramı, 222. Aydemir bu bağlamda Türk halkının politikaya ve DP'ye ilgisini izah etmeye çalışır. Ona göre Türkler şahsiyetine düşkün bir millettir ve günlük politika da şahsiyetleşme ve benlik ifadesini buldurur. "Ben de varım, benim de bu milletin içinde sözüm var kompleksi" devreye girer. DP ile kalabalıklar kendilerini buluş aşamasına geldiler, CHP'nin baskısından kurtuldular, mülkî ve askerî amirlerin taşradaki tahakkümü azaldı. Aydemir, Tek Adam III, 92.

189 Aydemir, Menderes 'in Dramı, 230.

190 Aydemir, Menderes 'in Drami, 112. 
halk adamı olmak için zarurî bir şart olan devlet adamı olamamış, demagog olmuş, sorumluluk seciyesi yüksek irade gösterememiştir. ${ }^{191}$

Aydemir' in eserlerinde DP ve Menderes'e dair eleştirel tutum ön plandadır ancak Kemalist ve CHP'li birisi olarak nitelenen birisi için bu gayet doğaldır. Buna mukabil Aydemir, yazıldığı dönemin koşulları da hesaba katılırsa, hem yukarıdaki paragrafta da müşahede edileceği üzere hem Menderes'e hem de DP'ye dair olumlu sözler de sarf etmiştir. Aydemir, halkın DP'ye oy vermesi ve iktidara getirmesinde "ruhî faktörlerin" ön planda olduğunu zikretse de, bu ruhiyatta iktisadî ve siyasî sebeplerin önemli rol oynadığını belirtmişti. ${ }^{192}$ CHP'nin iktisat siyaseti bakımında "kısır, kararsız, yönsüz, verimsiz" haline ve iktidar yorgunluğuna karşı DP memlekette geniş bir iş hareketi yaratmış, sosyo-ekonomik yapıda temel nitelikte etkiler bırakmıştı. ${ }^{193}$ Köylüye makine bu dönemde girmiş, biçerdöverler yalnız devlet çiftliklerinde görülürken, halk topraklarında da görülmeye başlamış, mevcut traktör sayısı 4000'den 44.000'e çıkmıştı. ${ }^{194} 1923$ 'den beri gelen temelde kapitalist yapıya yöneliş DP iktidarında gelişmiş, bütün tüketim sanayii kollarını içine alan endüstriyel atılım DP döneminde başlamış, iç pazarda kapitalist bünyeleşmenin sınaî temeli bu dönemde atılmıştı. Cumhuriyet döneminde “yol inşacılığının ilk ve verimli” devresi bu dönemde başlamış, barajlar, limanlar inşa edilmek suretiyle kalkınma hamleleri gerçekleşmişti. ${ }^{195}$ Hulasa, DP döneminde önemli kalkınma hamleleri olmuştu ama Aydemir'e göre DP olmasaydı da kalkınma olurdu zira II. Dünya Savaşı sonrası dönem sanayileşme, kalkınma dönemi idi yolların, fabrikaların, barajların yapılmadı̆̆ bir yer yoktu. Seylan, Birmanya, Afrika bile sanayileşmişti. ${ }^{196}$

Aydemir nezdinde 14 Mayıs 1950, yani DP'nin iktidara geldiği gün aynı zamanda bir rejim değişikliği idi ${ }^{197}$ ve bu minvalde DP'nin tarihî misyonu artık batılı manada demokrasiyi işletmek olmalıydı. ${ }^{198}$ Hâlbuki bu misyonu ifa etmesi gereken DP ile CHP arasında esaslı farklar yoktu. Her ikisi de "tek şef, tek parti, tek otoriter hükümet sistemini” temsil eden zihniyetten doğmuştu ve DP içinde yetiştiği zihniyetten kendini sarfı nazar edememişti. ${ }^{199}$ DP baştan sona Halk Partisi ve onun alışkanlıklarını devam ettirirken, kendisini "tek parti ve havası özleminden” soyutlayamamışt. ${ }^{200 ~ “ T e k ~ p a r t i ~ r e j i m i ~ v e ~ d i s i p l i n i ” ~ D P ' d e ~ d e ~ 1923 ' d e n ~ b e r i ~}$

191 Aydemir, Tek Adam III,348. Aydemir demagogu şu sözlerle tanımlamaktadır: "Demagog; sokağı kullanan, sokağa dayanan, sokak kalabalıklarını ve bu kalabalıkların basit enstenktlerini, basit tepkilerini, millî şuur ve millî irade sayan adam demektir. Ve demagoji; işte bu sokak kalabalıkları ile; cehaletin, aşağılık duygularının uyandırılması ve bu kalabalıkların sürüklenmesi için, demagog'un kullandığı basitsöz ve mantık silahı demektir”. Bk. Aydemir, Lider ve Demagog, 91.

192 Aydemir, Ikinci Adam III, 238.

193 Aydemir, Ikinci Adam III, 215.

194 Aydemir, Menderes 'in Dramı, 238.

195 Aydemir, İkinci Adam III, 225-231.

196 Aydemir, Menderes 'in Dramı, 273.

197 Aydemir, Ihtilalin Mantığ 175.

198 Aydemir, Ihtilalin Mantığ, 167.

199 Aydemir, Menderes 'in Dramı, 262-265.

200 Aydemir, Menderes 'in Dramı, 181. 
süregelen geleneğin devamı olarak yürütüldü. ${ }^{201} \mathrm{DP}$ kadrosu ile CHP kadrosu arasında sosyal yap1 ve dünya görüşü açısından önemli farklar yoktu. ${ }^{202}$ Türkiye'de demokrasi idealizm ve doktrin yolundan değil politika yönünden gelmişti ${ }^{203}$ ve bir doktrin partisi olmayan "orta yol partisi” mevkiinde olan DP, CHP'den sadece kadro değil program da aktarmıştı. Zaten çok partili düzende doktrin partisi değilseniz, programlar hep birbirine benzer ${ }^{204}$, orta yol partilerde "programlar yalnız yapılırken okunur ve o kadar parlamentolarda bu partilerin biri gelir, biri gider ve sonra gene o devran, alem gene o alem... Yani demokratik parlamento nizamı budur. ${ }^{205}$ Mesela DP'nin programındaki “devletçilik” kısmının CHP'den hiçbir farkı yoktu. ${ }^{206}$ Menderes kendisinden önceki dönemin iktisadî sistemine "müdahaleci kapitalizm” diye eleştirirdi oysa kendisinden önceki dönemin iktisadî vasfiyla kendi dönemi arasında bir fark yoktu, her ikisi de kapitalizme dönük karma ekonomi nizamı idi. ${ }^{207}$

“Atatürk'ü devam ettirmek ve ikmal etmek"; Aydemir'e göre Atatürk'ün ölümünden sonra bu mümkün olmamıştı. Şimdi bunu gerçekleştirme sırası Demokrat Partideydi. DP ise daha Menderes'in ilk nutku olan 29 Mayıs 1950'de kötü sinyaller vermişti. Menderes cumhuriyet döneminde gerçekleşen inkılâpları, "halka mal olmuş veya olmamış inkılâp" diye tasnif ederek tartışmaya açmıştı. ${ }^{208}$ Mezkûr nutukta Menderes ayrıca, 14 Mayıs seçimlerinin o zamana kadar yapılanlarla ölçülemeyecek derece mühim bir inkılâp olarak tasvir etmişti. Aydemir, bu sözlerin kendisinden önceki inkılâpları hafifseme olarak değerlendirirken, Menderes'in bir "sosyal yapı" değişikliğini işaret ettiğini ve bunu da "isteyerek ya da istemeyerek" gerçekleştirdiğini düşünmekteydi. ${ }^{209}$ Menderes bu nutukta “Atatürk'ü anmamış”, çok partili düzene geçişin evreleri olarak saltanatın kaldırılması, halk hâkimiyetinin getirilmesi gibi aşamaları zikretmemek suretiyle arkada kalan bütün bağları koparmıştı. ${ }^{210}$ DP ve Menderes inkılâba mugayir olarak dini her anlamda siyasete alet etmiş, "milletin kendi dilinde okunan ezanları" daha iktidarının ilk günlerinde Arapça 'ya çevirtmekle, “ucuz bir kazanç tecrübesi” geçirmişti. ${ }^{211}$ Türkiye

201 Aydemir, Ihtilalin Mantı̆̆ 137.

202 Aydemir, Menderes 'in Dramı, 211. Mesela Aydemir'e göre Bayar bir tek parti adamıydı, DP'de iken bile ona göre en iyi nizam CHP nizamıydı. Bayar ayrıca özel teşebbüsçü de değildi, onun İktisat Bakanlığı süreci devletçilik uygulamalarının en yoğun olduğu dönemdi, özel sektör aleyhinde de bir sürü karar aldı. Bayar bir tek parti adamı ve mutaassıp bir devletçiydi. Bk. Aydemir, Menderes 'in Dramı,175-177.

203 Aydemir, Menderes 'in Dramı, 162.

204 Aydemir, Menderes 'in Dramı, 181.

205 Aydemir, İkinci Adam II, 444-445. Aydemir “orta yol” olarak nitelendirdiği merkez partileri şöyle tanımlamaktadır: "Bu partilerin hepsi halktan gelen seçim kanunları nispetinde halkoyuna dayanan iyi niyetlilerle, belirli görüşü olmayanlar veya kötü niyetlilerden, çıkarcı insanların toplumundan meydana gelen orta demokrat partilerdir. Bu yalnız bizde değil bütün çok partili demokratik parlamentolardaki bütün orta partiler için böyledir. Onun içindir ki, bu partilerin topladığı kalabalıklar, hayatları boyunca kah o yana, kah bu yana dalgalanır dururlar. Bk. Aydemir, Menderes 'in Dramı, 212.

206 Aydemir, Menderes 'in Dramı, 162.

207 Aydemir, Menderes 'in Dramı, 215.

208 Aydemir, Ikkinci Adam III, 110.

209 Aydemir, İkinci Adam III, 39.

210 Aydemir, Menderes 'in Dramı, 207.

211 Aydemir, Ikkinci Adam III, 203. 
Millî Kurtuluş Hareketlerinin ilk örneği olmasına rağmen Bandung Konferans'ında Asya ve Afrika milletlerinin emperyalizme karşı müşterek duruşuna karşın DP hükümetinde Türkiye, Atatürk'ün değil "batının avukatlığını" yapmıştı. ${ }^{212}$ Tunus, Cezayir, Fas istiklal mücadelesini “Fransa'nın iç meselesi” sayarak Atatürk'ün ruhunu incitmişti. ${ }^{213}$

Aydemir'e göre çok partili rejimlerin henüz gelenek haline gelmediği ve iktidarın "her şey" demek olduğu Türkiye gibi “az gelişmiş” ülkelerde "iktidarın soysuzlaşması” dikta temayülü ile başlar. Ona göre DP liderleri de kendilerini bu siyasî eğilimden kurtaramamıştı. ${ }^{214}$ Çok partili nizamda kimse memleketin tek söz sahibi değilken, Menderes "kan davası" peşine düşmüştü. ${ }^{215} 1957$ seçimlerinden sonraki süreçte üniversite rektöründen üniversite öğrencisine, gazeteciden ana muhalefet partisine kadar muhtelif kesimlerde "burukluk" vardı ancak DP ve Menderes, sokak kalabalıklarını, pazar yeri kalabalıklarını memleketin "efkâr-1 umumiyesi” zannediyordu. ${ }^{216} \mathrm{O}$ kabalalık ruhiyatını bilmek ve ona gereken değeri vermek lazımdı. Zira sokak "ne şuur ne de fikir hele hele millî şuur" değildir, sokağın dili başkaydı. ${ }^{217}$ Sokağın "kaypak gösterilerini”" halkın bağlılığı sanan Menderes ise aslında yalnızdı. ${ }^{218}$ Aydemir'e göre CHP elbette DP'yi tahrik etmişti ama tahriki başlatan DP idi, demokrasinin "hem savaşçısı hem de kundakçısı" olmuştu. Siyaseti halka mal ederken, kalabalıkların her şeyi kapmaya ve benimsemeye müsait ruh yapılarında "illetli” bir durum oluşmuştu. Bu da "zaten nazik, illetli, çelişmeli” bir nizam olan demokrasinin "hastalığı” ya da inkârı olmuştu. ${ }^{219}$ Üniversitelerin protestosu ile artık "fikir" hareketlenmiş ve ordu da bu fikir doğrultusunda aksiyona geçmişti. 220

\section{5- Aydemir'in Tarihî Metinlerinde Millî Birlik Komitesi Dönemi Eleştirileri}

27 Mayıs 1960 günü ordu DP iktidarına müdahale ederek darbe gerçekleştirmişti. DP iktidarına son veren ordu kendi üyelerinden müteşekkil Millî Birlik Komitesi’ni oluşturdu ve Cemal Gürsel'in Devlet Başkanlığında ülkenin yönetimini üstlendi. Aydemir'e göre “İhtilal ne iyidir, ne fenadır. Eğer şartlar birikirse ihtilâl kaçınılmaz bir zarurettir. İhtilal bu şartları görebilenlerle, göremeyenler arasında, bir darbeyle sona eren bir aksiyon işidir."221 27 Mayıs sabahı da “hepsi de iyi niyetli, genç, temiz" askerler, 1876'da, 1908'de ve 1919'da olduğu gibi

212 Aydemir, Ikkinci Adam III, 327.

213 Aydemir, Suyu Arayan Adam, 392. Tanıl Bora Falih Rıfkı'nın, Kemalizm davasını “Türk kafasını Arap kafasından ayırmak" sözü ile açıkladığını ve 60’lı yıllarda yükselen Kemalizme “anti-emperyalist” misyon biçme davasından müşteki olduğunu dile getirir. Bora’ya göre ise Türkiye'nin Cezayir oylamasında “çekimser kalması”, Kemalizmin anti-emperyalist öncülük iddiasının simgesel çöküşüdür. Bk. Bora, Cereyanlar, 163.

214 Aydemir, Ikinci Adam III,251.

215 Aydemir, Menderes 'in Dramı, 294. Aydemir'e göre Menderes diktatör değildi çünkü diktatör ölebilir, ama acze düşmez ve teslim olmaz. Menderes elbette ki diktatör değildi zira diktatör olabilecek vasıf kendisinde yoktu. Bk. Aydemir, İkinci Adam III, 286.

216 Aydemir, Ikinci Adam III, 256.

217 Aydemir, Menderes 'in Dramı, 338.

218 Aydemir, Ihtilalin Mantığ 339.

219 Aydemir, Ikkinci Adam III, 410.

220 Aydemir, Menderes 'in Dramı, 397.

221 Aydemir, Menderes 'in Dramı, 350. 
devletin "başı sıkıştıkça" ordunun işlere müdahale etme geleneğini yansıtmıştı. ${ }^{222}$ Darbeden bir gün sonra ise "bilginler" tarafından bir Anayasa Komisyonunun teşkil edilmesi ve bu komisyonun darbenin gerekçelerini sunarak "meşruiyet fermanı" ilan etmesiyle darbe "ihtilâle" dönüşmüştü. ${ }^{223} \mathrm{Bu}$ anayasa komisyonu raporu daha önce hiçbir ihtilâle nasip olmamıştı zira rapor ihtilâle meşruluk ve hukuki dayanak sağlamıştı. ${ }^{224}$ Ancak ihtilâl "inkılâba" dönüşmeyecekti.

Aydemir'e göre ihtilâlin “ilk zaafı” lider yaratamaması olmuştu. Gürsel lider değil başkandı, hâlbuki her ihtilâl bir öncü kadro ile bir lider hareketidir. ${ }^{225} 1908$ ve 1919'da lider vard1 ${ }^{226}$ ancak Gürsel ihtilâl sonrasına yön tayin edecek bir "ihtirası" haiz karakter değildi. ${ }^{227}$ İhtilal komitesinde veya ihtilâlin yüksek konseyi olan MBK' de ise "hareket, program ve görüş birliğgi” yoktu. 228 27 Mayıs "ne bir doktrin ne de bir ideoloji" hareketi oldu ne de herhangi teorik bağlantılara dayanan bir fikir atılımı oldu zaten öyle bir "davası" da yoktu. ${ }^{229} 27$ Mayıs'ın aktif subayları Fevzi Çakmak'ın ordusundan yetişmişlerdi bu ordudan "dünyanın nereye gittiğini bilmeyen" askerler yetişirdi. Dünya “ihtilâlci sosyalizm”, "süper emperyalizm” tartışırken Harbiye'de gazete okumak bile yasaktı. Dünya değişmiş, "robot askerler” dönemi geçmişti ancak biz ancak ufku "Beyaz Zambaklar Ülkesinde" 230 okuyacak askerlere sahiptik. Atatürk'ün “orduyu siyaset dışında tutma" geleneği, ordunun "büsbütün pasifleşmesi”" şeklini almıştı. ${ }^{231}$

Atatürk inkılâbı yapmış ancak "bu inkılâp" tamamlanamamış, devam ettirilmemiş, ikmal olmamıştı. Atatürk'ün sosyal yapıda "fethettiği siperler” bile sarsılmıştı. Atatürk'ün geleneğini tevarüs eden ihtilâlciler 27 Mayıs hareketini “ekonomik, sosyal, politik” bünye değişikliklerine dönüştürmedi zaten böyle bir "ufukları" da yoktu. Ancak 27 Mayıs bir anayasa vaat etmesi dâhilinde bir darbe değil bir "ihtilâldi" zira anayasa ekonomik, sosyal, politik müesseseler, reformlar demekti. Hâlbuki Millî Birlik Komitesi "üç ay sonra yeni seçimler” taahhüt ediyordu, reformların kaderi "üç aylı bir mizansene" ondan sonra da "kalabalıkların oy gösterisine" birakılamazd1. ${ }^{232}$

Aydemir'e göre elan Ortadoğu'da bilhassa Mısır'da ihtilâlci kadro, etrafında bazı sosyal zümre ve sınıflarla hareket ederek uzun vadeli hedefler çiziyor, ihtilâli "inkılâba" döndürüyordu. ${ }^{233}$

222 Aydemir, Lider ve Demagog, 78.

223 Aydemir, Ihtilalin Mantığ, 357.

224 Aydemir, İkinci Adam III, 458.

225 Aydemir, Ikinci Adam III, 448.

226 Aydemir, İhtilalin Mantığ, 350. 1900-1908 arası nesil onlar ki engin ve ateşli savaşçılardır, idealist birer mana taşıyan ihtiraslarına sınır yoktur... Yenilgiyi kabul etmezler. Mücadeleleri nerde biterse orada yeniden başlarlar. Gürsel bunlardan değildi. Bk. Aydemir, Menderes 'in Dramı, 360.

227 Aydemir, Ikinci Adam III, 471.

228 Aydemir, Ikinci Adam III, 491.

229 Aydemir, Ihtilalin Mantığ, 313.

23027 Mayıs ihtilâlinden sonra komite üyelerinin önemli bir kısmı, Cumhuriyet gazetesinde yapılan röportajlarda en çok etkilendikleri kitap sorusuna, "Beyaz Zambaklar Ülkesinde” eseri yanıtını vermişti. Yalçın Küçük, bu eserin 27 Mayıs'1 gerçekleştiren subaylar nezdinde etkisinin, "Forum" dergisinden bile daha tesirli olduğu görüşünde Bk, Küçük, Aydın Üzerine Tezler:3,201.

231 Aydemir, İkinci Adam III, 475-477.

232 Aydemir, Ikkinci Adam III, 471-473.

233 Aydemir, İhtilalin Mantığ, 382. 
Bu minvalde, Mısır'ın lider Nasır'a yönelik sitayişkâr sözlerine metinlerinde sıklıkla müşahede edilen Aydemir'in²34, 27 Mayıs sürecinde MBK'nin "Nasır' '” olarak takdim edilen Alparslan Türkeş $^{235}$ ve onun gibi düşünen subaylarla, diğer subaylar arasında MBK içerisinde yaşanan ihtilafa dair değerlendirmeleri ilgi çekicidir. Aydemir'e göre 27 Mayıs idaresi iki ayrı cereyan yaratmıştır. Bunlardan ilki "batılı manada memlekette bir hukuk devleti ve demokrasi meydana getirmek", ikinci cereyan ise "ihtilâle inkılâpçı bir hava getirerek inkılâbın meydana getirebileceği sosyal değişimleri gerçekleştirmek” istemişti. ${ }^{236}$ Birinci grubu Gürsel ve Madanoğlu’nun başını çektiği klik, ikinci grubu ise Türkeş'in ön planda olduğu diğer subaylar teşkil ediyordu ve bu ihtilaf 13 Kasım 1960 tarihinde, ikinci grubun komiteden tasfiyesiyle sonuçlanmıştı. Aydemir ise tasfiyeyi gerçekleştiren grubun "haklı olduğu" çünkü ikinci grubun "sonu belli olmayan bir macerayı" savunduğunu ileri sürmüştü. ${ }^{237}$ Aydemir'e göre Türkeş “gelişigüzel ve sıradan” bir adam değildi kendinden önceki nesline "ihtiraslı ve mücadeleci”" kurmay tipini temsil ediyordu. Ancak Türkeş ve arkadaşları yakın çağın akımları, Tanzimat’tan itibaren Türkiye'de gelişmelerin tarihi ve güncel problemleri üzerine derine inen fikrî terkipler bakımından yeterince hazırlıklı değildi. ${ }^{238}$ Bundan ötürü tasfiye olan grup "sosyal bir doktrinden" mahrum kalarak "1rkçılıktan sosyalizme” kadar dağılan ve bütünlük arz etmeyen bir yapıya bürünmüştü. 239 İhtilal zafere ulaşınca, ihtilâl kadrosunun parçalanması ihtilâllerin değişmez bir kanunuydu. 1789 Fransız İhtilalinden, Bolşevik Devrimine hatta Türkiye’nin Millî Kurtuluş Hareketi’ne kadar bütün ihtilâllerde bu kanun geçerli olmuştu. 27 Mayıs da bu kanuna "baş eğerek" kısa sürede parçalanmış ve teşebbüs gücünü yitirmişti. ${ }^{240}$

\section{Sonuç}

Kendisini Suyu Arayan Adam olarak nitelendiren Aydemir, hayallerini ve hayal kırıklıklarını tarihî metinlerine yansıtmıştı. Enver Paşa ya da Menderes örneğinde görüldügüü üzere, mümkün mertebe objektif olma kaygısı, döneminin ve temsil ettiği mahallenin ezberlerine karşı gelse de bazen "hayalleri” istikametinde temennileri de mevcuttu. Millî Kurtuluş Hareketi olarak gördüğü Atatürk dönemine, mevcut sömürgelere/yarı sömürgelere emsal olma misyonu biçmesi ve Atatürk sonrası dönemi bu minvalde eleştirmesi bu noktada düşünülmelidir zira birçok yerde

234 Nasır, Mısır'da İngiliz hâkimiyetinden rahatsız olan ve bu minvalde Mısır Kralı Faruk'u devirerek iktidara gelen "Hür Subaylar" hareketinin önemli isimlerinden birisidir. Nasır daha sonra ihtilâlin lideri General Necip'e “iç darbe" gerçekleştirerek devirmiş ve ülkenin başına geçmiştir. 1955 yılında Süveyş Kanalı'nı millîleştiren, toprak reformunu tatbik etmek gibi birçok radikal reforma imza atan Nasır; "milliyetçi, sosyalist ve Pan-Arabist" fikirleriyle hem Ortadoğu' da hem de dünyada tesirler yaratmıştır. Nasır için bk. Zeynep Güler, Süveyş 'in Batısında Arap Milliyetçiliği: Mısır ve Nasırcılık, (İstanbul: Yeni Hayat Yayıncılık, 2004). Aydemir'in Nasır yorumları için bk. Aydemir, Ikinci Adam II, 352, Aydemir, Ikkinci Adam III, 330.

235 Ferit Salim Sanlı, Cumhuriyetçi Köylü Millet Partisi’nden Milliyetçi Hareket Partisi'ne Tarihî Süreç, İdeoloji, Politika (1960-1969) (İstanbul: Ötüken Yayınları, 2019),128-129.

236 Şevket Süreyya Aydemir, “ 27 Mayıs İhtilalinde İki Cereyan”, Yön, 30 Mayıs 1962, 8.

237 Aydemir, “27 Mayıs İhtilalinde İki Cereyan”, 8.

238 Aydemir, İkinci Adam III, 501-502.

239 Aydemir, “27 Mayıs İhtilalinde İki Cereyan”, 8.

240 Aydemir, Lider ve Demagog,75. 
bilhassa Lozan'dan sonra Atatürk'ün tamamen "batı dairesine” girme tasavvurunu zikretmişti. Ya da 1921 Anayasasından bu kadar sitayişle bahsetmesini yine söz konusu temenni bağlamında değerlendirmek gerekmektedir. Buna mukabil Aydemir'in anayasaya aşkın bir değer verdiği bilhassa 1924 anayasası eleştirilerinde müşahede edilir.

Aydemir hem İnönü’yü hem Menderes'i hem de MBK'yi, “Atatürk dönemini ikmal etme/ derinleştirme" nazarından tenkit etmiştir. Atatürk dönemini eleştirirken ise genelde Atatürk'ü değil dönemin Başbakanı İsmet İnönü’yü adres göstermesi, Türk tarihyazımında sıklıkla görülen bir pratiktir. Ancak Aydemir'e göre İnönü dönemi "karşı darbe" dönemi değildir zira bu sefer de İnönü’yü eleştirirken, tenkit dairesini 1923-1950 arasına hasretmiş ya da Menderes'in kalkınma başarılarını överken de Atatürk dönemini bazen zımnen bazen alenen eleştirilebilmiştir.

Aydemir, 1876, 1908,1919 ve 1960’a önemli misyonlar biçmiş ancak bu hareketlerin, Türk modernleşmesinin “gereklerini” yerine getirmediği kanaatinin yazınında paylaşmıştı. Ona göre bu hareketlerin getirdiği yapı, zamanın ihtiyaçlarına cevap vermiyordu. 1908 sadece 1876 anayasasını getirmek istiyor, 1924 anayasası 19. yüzyılın liberalizmine tekabül ediyor, Atatürk çağdaşlarının "doktrine dayanan nizama” geçtiği dönemde herhangi bir ideoloji ortaya koymuyor, "çok partili düzenin" adamı Menderes "tek partili düzene” göre siyaset yapıyor, 1960 darbesi ise muasır devrimlerin misyonunu ifa edemiyordu. Aydemir'in metinlerinde dönemler değişse de sorunların temeli aynıydı. İhtilalleri gerçekleştiren ordu mensupları, formasyon olarak oldukça yetersizdi ve herhangi bir fikrî sistemi/doktrini haiz değildi. Bunu aydınlar gerçekleştirecekti oysa Türk tarihinde "kahramanlar, fatihler" mebzul miktarda iken ilim adamları o nispette değildi ve aydın Osmanlı'dan itibaren yükselmenin yolunu devlete intisap etmekte bulmuştu. Dolayısıyla "bürokratik zihniyet" aydına sirayet etmişti ve bu yapıdan “idealist aydın” çıkamazdı. Aydemir'in, Türk fikir tarihinde sıklıkla yer alan Akçura-Gökalp mukayesesine ve değerlendirmelerine bu nazarla tahlil etmek ilginçtir zira Gökalp Osmanlı tipi aydını temsil ederken, Akçura Rusya formasyonunu temsil ediyordu.

Aydemir Fransız tipi tedrisat ile Sovyet eğitimini imtizaç ettiren bir terminolojiyi haizdi. Kendi neslinin de etkilenmiş olduğu Jakoben, Le Bonist ve Platon'dan mülhem bir “meritokrasi” peşindeydi. Bu bağlamda tek parti yönetiminin otoriter uygulamalarını alkışlayan ama yeterli bulmayan bir figürdü. Bilhassa Sovyet tecrübesi ve Marksist terminolojiye hâkimiyeti ise, döneminin ötesinde bir sosyo-ekonomik tahlil ve üst-yapı tahlillerini beraberinde getiriyordu. Bundan ötürü de 1930'lu yıllarda yazdıkları, "bu düzen değişmeli” mottosunun hâkim olduğu 1960’lı y1llarda oldukça teveccüh gördü. 1960’lı yıllar ayrıca bütün dünyada olduğu gibi Türkiye'de de “doktrinler” çağı idi. Türkiye'de ilk defa “doktriner partiler”, TİP/CKMP/MHP/ MNP örneklerinde olduğu üzere teşekkül etmişti. Çok partili nizama pek de sıcak bakmadığı anlaşılan Aydemir'in( hatırlanacağı üzere onun için çok partili nizam ne iyi ne de fenadır tıpkı ihtilâller gibi) de biyografilerini bu dönemde kaleme alması ve mezkûr ruhu yansıtması bu bağlamda da önemlidir. 
Hakem Değerlendirmesi: Dış bağımsız.

Çıkar Çatışması: Yazar çıkar çatışması bildirmemiştir.

Finansal Destek: Yazar bu çalıșma için finansal destek almadığını beyan etmiștir.

Peer-review: Externally peer-reviewed.

Conflict of Interest: The author has no conflict of interest to declare.

Grant Support: The author declared that this study has received no financial support.

\section{Kaynaklar/References}

Aydemir, Şevket Süreyya. “ 27 Mayıs İhtilalinde İki Cereyan”, Yön, 30 Mayıs 1962, 8. İhtilalin Mantı̆̆l ve 27 Mayıs İhtilali. İstanbul: Remzi Kitabevi, 2.B,1976. İkinci Adam I. İstanbul: Remzi Kitabevi, 14.B, 2011. Ikinci Adam II. İstanbul: Remzi Kitabevi, 11.B, 2011. İkinci Adam III. İstanbul: Remzi Kitabevi, 9.B, 2011. “İnk1lâp Bitti Mi?”, Kadro, Mart 1932, 5-10. “İnkılâp Heyecanı ( Antusiasm)”, Kadro, Şubat 1932, 5-8. “Ziya Gökalp”, Kadro, Şubat 1932, 29-41.

Kırmızı Mektuplar Son Yazıları. İstanbul: Çağdaş Yay. 1979.

Lider ve Demagog. İstanbul: Remzi Kitabevi, 1997.

Makedonya'dan Orta Asya 'ya Enver Paşa I. İstanbul: Remzi Kitabevi, 1970. Makedonya'dan Orta Asya'ya Enver Paşa III. İstanbul, Remzi Kitabevi, 1972. Makedonya'dan Orta Asya'ya Enver Paşa II,( İstanbul: Remzi Kitabevi, 1971). Menderes 'in Dramı. İstanbul: Remzi Kitabevi,1969. Suyu Arayan Adam. İstanbul: Remzi Kitabevi, 42.B., 2020. Tek Adam I. İstanbul: Remzi Kitabevi, 10.B, 1985.

Tek Adam II. İstanbul: Remzi Kitabevi, 12.B, 1993.

Tek Adam III. İstanbul: Remzi Kitabevi, 11.B. 1992.

Bora, Tanıl. Cereyanlar: Türkiye'de Siyasî İdeolojiler. İstanbul: İletişim Yay. 2.B. 2017.

Carlyle, Thomas. Kahramanlar, Çeviren Reşat Nuri Güntekin, İstanbul: Semih Lütfü Kitabevi, 1943.

Ertan, Temuçin Faik. Kadrocular ve Kadro Hareketi Ankara: Kültür Bakanlığı Yay. ,1994.

Güler, Zeynep. Süveyş 'in Batısında Arap Milliyetçiliği: Mısır ve Nasırcılık. İstanbul: Yeni Hayat Yayıncılık, 2004. Kaçmazoğlu, H.Bayram.“ Bazı Bilim İnsanlarının Türkiye’deki Siyasal Düşün Tarihi Katkıları Üzerine Bir Deneme”, Modern Türkiye'de Siyasî Düşünce 9: Dönemler ve Zihniyetler. İstanbul: İletişim Yay. 2009, 233-248.

Karaosmanoğlu, Yakup Kadri. Atatürk. İstanbul: İletişim Yayınları, 5.B,1991. Zoraki Diplomat. İstanbul: İletişim Yayınları, 12.B, 2020. Politikada 45 Yll. İstanbul: İletişim Yay. 8.B, 2013. 
Karaömerlioğlu, Asım. “Türkiye’de Çok Partili Hayata Dönüşün Toplumsal Dinamikleri”, Toplum ve Bilim, 1 Ocak 2006, 174-191.

Karpat, Kemal. Türk Demokrasi Tarihi. İstanbul: Timaş Yay. 2010.

Kuyaş, Ahmet. "Yeni Osmanlılardan 1930'lara Anti-Emperyalist Düşünce”, Modern Türkiye’de Siyasî Düşünce 2:Kemalizm. İstanbul: İletişim Yay.6.B. 2009, 247-253.

Küçük, Yalçın. Aydın Üzerine Tezler 3. İstanbul: Tekin Yay. 3.B. 1999. Aydın Üzerine Tezler 5. İstanbul: Tekin Yay. 1988.

Özdemir, Hikmet. Kalkınmada Bir Strateji Arayışı: Yön. Ankara: Bilgi Yayınevi, 1986.

Sanl1, Ferit Salim. Cumhuriyetçi Köylü Millet Partisi'nden Milliyetçi Hareket Partisi'ne Tarihî Süreç, Ideoloji, Politika (1960-1969). İstanbul: Ötüken Yayınları, 2019.

Türkeş, Mustafa. “Kadro Dergisi”, Modern Türkiye’de Siyasî Düşünce 2: Kemalizm, 464-476.

Varel, Anıl. “Altmışlı Yıllar Türkiye’sinde Sınıf ve Siyaset: Meşruiyet Savaşımı, Siyasal Yükselişi ve İç Bölünmeleriyle TIP”, Türkiye’nin 1960’lı Yılları, Hazırlayan Mete Kaan Kaynar. İstanbul: İletişim Yay.2017.

Widmann, Horst. Atatürk ve Üniversite Reformu, Çeviren Aykut Kazancıgil- Serpil Bozkurt İstanbul: Kabalcı Yayınevi, İstanbul, 1999. 